\title{
Eastern Europe as a Laboratory for Economic Knowledge: The Transnational Roots of Neoliberalism ${ }^{1}$
}

\author{
Johanna Bockman \\ Congressional Research Service
}

Gil Eyal
Columbia University

Using Latour's concepts of "actor-network" and "translation," the authors show that neoliberalism's success in Eastern Europe is best analyzed not as an institutional form diffused along the nodes of a network, but as itself an actor-network based on a particular translation strategy that construes socialism as a laboratory of economic knowledge. They argue that socialism was made into a laboratory of economic knowledge during the socialist calculation debate of the 1920s and 1930s. An extensive debate during the Cold War is also documented and shows that a transnational network continued to be organized around attempts to connect the results obtained in the socialist laboratory with debates and struggles in Western economics. Finally, the drafting of transition blueprints in postcommunist Eastern Europe after 1989, with the participation of American economists, is shown to be a continuation of this transnational network.

After communist regimes in Eastern Europe collapsed in 1989, the new postcommunist governments have embarked, at various speeds, on neo${ }^{1}$ Some of the research for this article was done with the support of the International
Research and Exchanges Board (IREX), the Davis Center for Russian Studies at
Harvard University, the Institute for European, Russian, and Eurasian Studies at
George Washington University, and the Woodrow Wilson International Center for
Scholars. We would like to thank these institutions for their generous support. We
would also like to thank the Ford Foundation and the Library of Congress for access
to their papers. Many individuals read drafts of this paper, made important comments
and criticisms, and generously shared their knowledge and views with us. We would
like to thank Michael Bernstein, David Engerman, Peter Evans, Neil Fligstein, Sheila
Jasanoff and the participants in her Science Studies Research Seminar, Martha Lamp-
land, John Markoff, Ákos Róna-Tas, Yuval Yonay, and Andrew Zimmerman, as well

(C) 2002 by The University of Chicago. All rights reserved. 0002-9602/2002/10802-0002\$10.00 
liberal economic reforms designed to bring about rapid liberalization, macroeconomic restructuring, and, ultimately, privatization. Ever since, much has been written about the transition from communism to capitalism in Eastern Europe, with critics and adherents battling over the soundness of logic, as well as purported effects of neoliberal reforms. In this article, however, we would like to pose a different question about the reforms: What explains the fact that neoliberal ideas and policy recommendations have been adopted so rapidly, and almost unanimously, in post-1989 Eastern Europe?

Our answer will be that the roots of this rapid and strong embrace of neoliberalism reside in a transnational network composed of both American and East European economists. Within this network, we argue, a transnational dialogue was conducted, as early as the years of the Cold War, during the course of which neoliberal ideas were worked out and disseminated. Its existence helps explain why East European reformers, many of whom participated in this dialogue, not only perceived the need for neoliberal reforms, but also became some of the strongest global champions of such reforms.

What is surprising or counterintuitive about this answer? It runs contrary to the almost unanimous accord of scholars who believe that East European reformers were novices in market economics, at best "learning by doing," and needed to undergo a crash course under the tutelage of Western advisors. The view is, therefore, that these advisors exported Western neoliberalism to Eastern Europe and imposed it there with the support of Western governments and international economic agencies (Grosfeld 1992, pp. 62-63; King 2001, pp. 2-3; Kovacs 1991, 1992; Murrell 1995, pp. 166-67; Reich 1991, p. 220; Wedel 2001). In this article, however, we will show that East European reformers were converted into adherents of neoliberalism long before 1989 by participating in transnational dialogue and through jurisdiction battles over the role of economists under socialism. More important, we will argue that it is impossible to divide this transnational dialogue into an active, Western "author" of neoliberal ideas and policies and a passive, East European "recipient." Neoliberalism was not simply disseminated from West to East, but was made possible and constructed through the dialogue and exchanges that took place within this transnational network.

This argument runs contrary not only to extant explanations of the transition to capitalism in Eastern Europe, but also to what has been argued about the adoption and implementation of neoliberal policies in other parts of the globe, notably Latin America. Sociologists and political

as the $A J S$ reviewers. Direct correspondence to Gil Eyal, Department of Sociology, Columbia University, 1180 Amsterdam Avenue, New York, New York 10027. 
scientists have argued that the global success of neoliberalism was evidence for the dominance of Western and in particular U.S. economics, and that local policy makers adopted it in order to gain legitimacy visà-vis international financial institutions (Babb 2001; Centeno 2001; Markoff and Montecinos 1993). While it is clear that Latin America, the traditional "backyard" of the United States, is an altogether different case from postcommunist Eastern Europe, we think that there are also some more general theoretical reasons why our accounts differ.

Clearly, the question about the adoption of neoliberalism is a subspecies of a more general theoretical question about the causes of isomorphism in organizational fields (Powell and DiMaggio 1991). New institutionalist arguments, particularly those about "coercive" and "normative" isomorphism, have played an important role in explaining the widespread adoption of neoliberal policies and in resisting economistic explanations according to which states were adopting neoliberalism as the most rational and technically efficient response to a changing competitive environment (Babb 2001; Centeno 2001; Markoff and Montecinos 1993; FourcadeGourinchas 2000; Meyer et al. 1997). The considerations we present here, therefore, should not be taken as refutation of new institutionalist thinking, but as a contribution to it. We think that our focus on transnational ties and transnational dialogue helps to specify how global networks actually work in processes of institutional diffusion and what role local actors play in these exchanges.

We see transnational networks and transnational dialogue where others have seen merely imitation and imposition because of the attention we pay to the issue of reproduction. Isomorphism has customarily been treated as a sequence starting with innovation and ending with adoption and diffusion. Reproduction, however, should be isolated as a distinct analytical phase within this sequence. Simply put, for innovations to be imitated and diffused they must remain the "same thing" through these processes, that is, there must be some mechanism that keeps them together and protects and replicates them. For example, if neoliberalism is becoming global through processes of institutional isomorphism, what guarantees that the same set of policy recommendations is copied the world over and is not tinkered with and changed? Of course, if neoliberalism is a "theory," a set of logically consistent propositions as its adherents maintain, then it is easy to justify why it remains "the same" through diffusion-because it is "correct." But this is precisely the sort of rationalist fallacy against which new institutionalists warned. If neoliberalism, on the other hand, is a set of policy recommendations unified as an institution, the explanation of its reproduction is trickier. The answer given by institutionalists is that the process of institutionalization turns this set of rules into taken-for-granted: They are taken as "fact," and protected from 
scrutiny by force of habit or by avoidance of the cognitive effort required to question them (Powell and DiMaggio 1991, p. 15; Meyer and Rowan 1991, p. 44; Zucker 1991, pp. 85-88). This argument, however, is in tension with the stated preference of new institutionalists to treat actors as reflexive and knowledgeable (Powell and DiMaggio 1991, pp. 22-27), hence to treat taken-for-grantedness itself as provisional and revisable. Put differently, taken-for-grantedness is no answer at all for how institutional forms are reproduced; it merely signals the problem. As Jepperson puts it, the question is what kind of taken-for-grantedness is involved, and what are the conditions and mechanisms that either protect it from challenge, or render it vulnerable (Jepperson 1991, pp. 145-47, 152)? New institutionalists did not deal adequately with this problem. They either ignored it, in effect implying that reproduction was assured by the same external factors that facilitated the diffusion of institutional forms-fear of uncertainty, coercion, or the interests of experts (Powell and DiMaggio 1991, pp. 67-74; Babb 2001, pp. 16-21; Centeno 2001)—or they suggested that taken-for-grantedness was protected by decoupling formal institutional structure from an informal, and more reflexive, level of functioning (Meyer and Rowan 1991, pp. 57-58). As Guillen has noted with respect to Meyer's argument about the emergence of a global world society, this means that institutionalist analysis is couched at a very high level of abstraction (2001, p. 246). Isomorphism is demonstrated, but it is fairly empty, composed only of "myth and ceremony," while more concrete mechanisms are obscured (for a similar critique see Tilly [1999, pp. 407-9]).

It is not generally recognized that both Foucault and Latour have grappled with precisely this same set of issues and attempted to provide conceptual tools-respectively, "discursive relations" and "actor-network" - with which to approach it.

With the concept of "discourse," Foucault sought to avoid the same rationalist fallacy identified by new institutionalist sociologists (i.e., that theories or ideas are adopted because they are somehow "correct" and "true" (Foucault 1972, pp. 21-55, 79-105). His contribution was to reformulate the problem as one of reproduction: how to explain, without recourse to some knowledge of what the "truth" should be, that certain discursive "events" were replicated, while others disappeared. The answer, Foucault argued, was that discursive practice established a definite set of relations between discursive events, which worked to preserve them. Such relations carry a certain necessity, but not because they are taken for granted, not because actors do not think about them, but because they think with them, because they govern how the objects of discourse are formed or what modes of observation and formulation are available.

Latour (1987, 1993) continued this insight, but he gave it a more concrete and sociologically satisfactory form. He suggested thinking of any 
American Journal of Sociology

scientific artifact (a law, a discovery, an invention, a theory, a demonstration) as an "actor-network"; that is, as a network composed of a set of ties and alliances between human and nonhuman agents. He thus introduced agency into discourse by depicting it as an activity of constructing and weaving together a network of discursive relations. From this point of view, an explanation for the persistence and reproduction of institutional forms need not refer to external forces, nor must it be satisfied with a vague notion of taken-for-grantedness. Instead, the explanation can focus on the actual work of constructing a network and of establishing ties between statements, instrumentation, effects demonstrated in the lab, financial resources, the opinion and support of colleagues, and other such components. If a certain institutional form is reproduced and disseminated, this is in direct proportion to the amount of resources mobilized through network ties, to the strength of the ties forged, and to the capacity of interested actors to close them in a "black box"; that is, to hide the work needed to connect together the different elements of the actornetwork (Latour 1987, pp. 2, 131). If a certain institutional form fails to be reproduced and disseminated, it is because other actors were capable of opening the black box, then untying the network and pillaging its components for their own use. Latour (1987) explicitly opposes his own approach to the idea that innovations are "diffused" (pp. 132-41). Since institutional forms or scientific artifacts are networks of relations, what may seem as diffusion might be better construed as a lengthening of the network in order to mobilize crucial new resources needed to reproduce it or to protect it from attacks. By the same token, what new institutionalists depicted as imitative of given institutional forms should be understood as "translation"-meaning the ability of network builders to devise an interpretation that aligns their interests with the network's new recruits, whose support and resources are crucial for its survival (Latour 1987, p. 108).

This article seeks to demonstrate the usefulness of this approach in explaining the rapid success of neoliberalism in postcommunist Eastern Europe. In the first section, we begin our discussion of the origins of neoliberalism by going back to the debate about socialist economic calculation in the 1920s and 1930s. This debate was conducted between Austrian economists on the one hand, who argued that economic calculation was impossible under socialism, and neoclassical mathematical economists of a socialist bent on the other, who sought to show that socialist economic arrangements permitted calculation and were efficient. We do not think that this debate already contained neoliberal thinking in embryo, as the proverbial acorn from which the tree was to grow. But we try to show that it constituted an important discursive event, setting up socialism as a laboratory of economic knowledge. From a Latourian 
point of view, however, the essential question is how this discursive event was made replicable; that is to say how the results obtained in the socialist "laboratory" could be mobilized to support arguments about market relations. We show that each side in the debate developed a different translation strategy to align the interests of economists studying socialism with those who study capitalism: neoclassical mathematical economists minimized the institutional differences between socialism and capitalism and postulated formal equivalence between problems of mathematical planning; Austrian economists depicted the socialist laboratory as magnifying into systemic distortions what under "normal" market relations were small deviations, thus permitting a better appreciation of their significance.

This approach explains our focus on transnational dialogue and transnational networks, because in the years following the debate, if the discursive event was to be replicated, these translation strategies had to be used in order to construct transnational networks, which could mobilize the research done on socialism and connect it with Western economics. There is a burgeoning literature on the role played by networks and "epistemic communities" in global diffusion of institutional models (Adler and Hass 1992; Evangelista 1999; Haas 1990, 1992; Hall 1993; Keck and Sikkink 1998), but the reader can now appreciate in what way our Latourian approach is different. We emphasize that institutions themselves are actor-networks. Thus, institutional models are not simply passed along, copied and imitated via transnational networks, but are put together and reproduced through them. This is the chief reason why our account of the success of neoliberalism differs from other arguments using the framework of institutional isomorphism. In the second section of the article, we demonstrate the existence of two East-West discussions and two transnational networks of economists in the 1950s and 1960s. The first network was composed of mainstream mathematical economists speaking the common language of linear programming. The second network was composed of American libertarian economists, who at the time were a distinct minority battling against the reigning Keynesian orthodoxy, together with a no less embattled group of East European economists, who were becoming highly critical of political obstacles to economic reform under socialism. We show that both networks did not involve simply the diffusion and imitation of institutional models (in this case, economic theories and methodologies), but each was built around a particular translation strategy to connect the results obtained in the socialist laboratory to arguments about market economics. The linear programmers sought to demonstrate, under socialist conditions, that mathematical modeling of resource allocation could produce results superior to markets or at least as efficient as markets. The Austrian translation strategy meant that participants interpreted their exchanges as demon- 
strating that socialist institutional arrangements created systematic distortions of underlying market processes, analogous to the perverse effects of Keynesianism.

Moreover, we argue that the fact that this transnational dialogue was forgotten, and that later observers simply saw the diffusion of neoliberalism from West to East, is not accidental but a systematic feature of the way the actor-network was constructed. With very few exceptions, American economists tended to represent their socialist interlocutors as ignorant of Western economic theory. This meant that they could "black box" the discourse of their interlocutors and present it as simply "data," a report on the facts. Put differently, the very translation and alignment of interests facilitating the construction of the network also obscured how it worked: since socialism was to be a laboratory of economic knowledge, American economists could not see the contributions of their East European colleagues as anything but a report on "reality." Eastern European economists, for their part, were content with this translation. They were engaged in a struggle against bureaucrats and party officials for professional jurisdiction over the economy, and they made use of the prestige of their Western colleagues, as well as the resources that the latter commanded, in order to support their claim. Thus, as Latour (1987) would suggest, the fact that the transnational dialogue was forgotten was a function of the capacity of network builders to position themselves at an "obligatory point of passage" within the network (pp. 150, 245). From this point Western economists controlled the flow of key resources to other nodes of the network; by the same token they also mobilized and appropriated the work performed there. ${ }^{2}$

It follows, therefore, that if libertarian economists wanted to challenge their Keynesian opponents, they had to obtain a foothold in the socialist laboratory so that they could open up and rearrange the black boxes of "facts" produced there. It was crucial that they too would recruit East European economists as allies, in particular those who were critical of socialism. In the third and final section of the article we seek to show that the rapid adoption of neoliberalism in Eastern Europe, which was

\footnotetext{
${ }^{2}$ It should be clear, therefore, how our argument differs from other critiques of the idea that globalization leads to homogenization and Americanization (Appadurai 1996; Nederveen Pieterse 1992). As Wimmer (2001, p. 438) has noted, most of the arguments about hybridization and creolization do not break with the view of a single, overarching principle of global isomorphism. They merely shift the valence to peripheral practices of resistance, which they depict as subverting globalization. Our version of "hybridity," however, is different and closely follows Latour (1993, pp. 41-43): the idea of a single logic of globalization-cum-Americanization is a myth perpetuated by the pattern of forgetting and appropriation characteristic of transnational actor-networks. The hybrid is not what resists globalization, but the very way it works. On the concept of jurisdictional struggles, see Abbott (1988).
} 
perceived as a paradigmatic case of diffusion and imitation, is better grasped as another case of translation and alignment of interests. We show that neoliberal transition policies, especially the notorious recommendation of "shock therapy," were not simply the dictate of Western advisors, but reflected the experience and interests of a specific group of East European economists. These economists were engaged in an ongoing jurisdictional battle over the reform of socialist economies that had begun as early as the late 1960s. In the course of these struggles they opened up the "black boxes" constructed by their opponents and devised an opposing representation of socialist economies as chaotic, inefficient, and in need of radical shock therapy. It was this vision that they offered in the transition period, as "the facts," to their Western interlocutors, promising the ultimate laboratory experiment to vindicate neoliberalism.

\section{THE DEBATE ABOUT SOCIALIST ECONOMIC CALCULATION}

The socialist calculation debate began in 1920 with the publication of an essay by the Austrian economist Ludwig von Mises ([1920] 1935), which argued that socialist economic arrangements precluded the possibility of rational economic calculation and thus could not allocate goods as efficiently as markets. The debate continued in a variety of venues at least until 1940. It is customary to distinguish two stages in the debate (Lavoie 1985b): in the first, conducted mainly between von Mises and Marxist economists, the major issue in dispute was whether the labor theory of value could serve as an adequate basis for economic calculation; in the second, prompted by the "economic theory of socialism" proposed by the Polish economist Oskar Lange (1938), the debate was conducted between neoclassical economists sympathetic to socialism and the Austrian economist Friedrich von Hayek; here, the major issue was whether central planning could achieve rational pricing (Hayek 1939). While the first stage of the debate could be seen as one of the ideological battles in the war between Marxists and liberals, the second stage involved a struggle internal to neoclassical economics and concerned not only ideology, but also the control of the profession. We will focus, therefore, on the second stage of the debate, though a full sociological analysis of this debate is beyond the reach of this article. Rather, we will merely try to show how Lange's theory and Hayek's response collaborated in producing a discursive event-establishing socialism as a laboratory for economic knowledge-which the two adversaries put to different uses by relying on two different translation strategies.

In what sense was the socialist calculation debate part of a professional struggle within neoclassical economics? As Yonay (1998) has shown, the 
interwar years in the United States were a time of heightened struggle over control of the economics profession. Initially this struggle was between neoclassical and institutionalist economists; later, those factions were challenged and eventually defeated by a new and younger group of neoclassical mathematical economists (pp. 77-99, 184-95). Oskar Lange, studying in the United States in the 1930s, belonged to this latter group, as did other economists who later wrote about socialism. Thus, we suggest that when these individuals proposed to show that socialist economic planning could achieve efficiency and rational pricing they were not merely defending socialism, they were also recruiting allies into the emerging network organized around the new mathematical techniques. Similarly, the other side in the debate, Austrian economists, did not engage in the debate simply because they were antisocialist from the start. In fact, it was only in the course of the debate about socialist economic calculation that the Austrian "school," which previously was understood to be a more or less stylistic difference within the larger marginalist revolution, came to be sharply differentiated. It acquired its distinctive character by challenging the relevance of the new mathematical techniques (Boetkke 2000, pp. 6-7; Lavoie 1985b, pp. 3-4; Shearmur 1996, pp. 33-35, 40-41).

Mathematical economists based their work on general equilibrium theory, which the Swiss economist Leon Walras had developed. As Yonay (1998) argues, the victory of this group in later years cannot be ascribed simply to the greater usefulness or validity of mathematical techniques (pp. 184-95). General equilibrium models required highly restrictive and simplifying assumptions of perfect competition and perfect knowledge, and thus were vulnerable to charges that they were not realistic. ${ }^{3}$ Economists typically used these models to show that the system of equations, which described the preferences of all consumers and the production functions of all commodities, was solvable in principle, but it could not be used to find actual preferences and production functions. Moreover, to simulate the workings of markets, they employed the highly stylized fiction of an auctioneer announcing prices and taking bids. It was for these reasons that research on socialism held special importance for mathematical economists. The fiction of the auctioneer could be represented by a concrete institution, the central planning authority of the socialist state; the system of equations no longer described a simulation divorced from actual values, but could be seen as the very means by which actual economic activity is directed. The simplifying assumptions necessary for the

\footnotetext{
${ }^{3}$ This very same charge was directed by the institutionalists, with some success, against the deductive approach employed by the earlier generation of neoclassical theorists like Knight and Viner (Yonay 1998, pp. 80-94).
} 
model could then be translated into directives issued by the central planning authority. Lange (1938) suggested that market socialism would work in the following way: first, the central planning authority drafts clear and binding rules, which include the instruction for managers to approximate in their pricing the marginal cost of production (pp. 72-98). These rules are published, so all economic actors are familiar with them. At the second stage, production and competition begin on the basis of these rules and prices. The third stage is iterative, as the central planning authority continuously adjusts the rules and prices in accordance with the feedback it gets from the managers. Eventually, efficiency and equilibrium are reached. In many respects, Lange's "socialism" was simply a general equilibrium model put into practice. This is why he argued that it could be mathematically demonstrated that a socialism thus organized would achieve market-clearing prices and equilibrium more efficiently than free competition.

We can see, therefore, what kind of discursive event took place through Lange's intervention in the debate: socialism was given a privileged status as a laboratory of economic knowledge, wherein results could be obtained that were not possible under capitalism and which also bolstered the legitimacy of the new mathematical techniques. In order to make the results obtained in the socialist laboratory count in debates between Western economists, however, Lange's proposal included a specific "translation strategy" that was designed to align his own interests with those of mathematical economists more generally. The general features of this strategy are evident in Lange's model, which constructs a relation of formal equivalence between the socialist laboratory and capitalist market relations:

1. As against the Marxist economists, Lange agreed with von Mises and his followers that the essential nature of the economic problem under capitalism and socialism was identical. In both cases, the question was how to optimally allocate scarce resources to achieve desired ends (Lange 1938, pp. 98-99; Hayek 1935, pp. 4-7);

2. Lange also maintained that the institutional differences between socialism and capitalism did not modify the essential nature of the technique required to solve this problem, namely some form of "programming," which iteratively calculates marginal costs of production and corrects them on the basis of continuous feedback until a point of equilibrium is achieved. General equilibrium models represented such technique. "The formal analogy . . between the principles of distribution of resources in a socialist and in a competitive regime of private enterprise makes the scientific technique of the theory of economic equilibrium which has been worked out for the latter also applicable to the former" (Lange 1938, pp. 107-8); 
American Journal of Sociology

3. Finally, while the technique was the same, Lange (1938) argued that socialism allowed one to apply it without the institutional limitations it faced under capitalism (pp. 101-5). The institution of private property limited the application of the technique because it did not permit independent iterations needed to determine the most rational allocation of resources and because it left out a variety of factors as "externalities," which were not taken into account in the calculation of prices.

While Lange obviously meant these arguments to make "the economist's case for socialism," they could also function in the opposite way-as a translation strategy that permitted one to use socialism as a laboratory for the new mathematical techniques (Lange 1938, p. 98). As we shall demonstrate in the next section, this is how most later mathematical economists perceived the significance of their contacts with East European economists and their joint work on market reforms under socialism (Arrow and Hurwicz 1960, pp. 34-43, 76-81).

Similarly, it is possible to see Hayek's intervention in the debate and his response to Lange as partaking of the same discursive event but using a different translation strategy in order to connect it with a different version of neoclassical economics. As Shearmur (1996, p. 48) notes, up until 1937 Hayek's thought was dominated by general equilibrium theory, and thus the Austrian "school" seemed to merge with other strands of neoclassical economics. When Hayek moved to Britain and won a prestigious chair at the London School of Economics, he found himself shut out of the more influential discussions of economic policy in the circle around Keynes (Yonay 1998, p. 47). In his response to Lange, however, only three years later, Hayek formulated a discursive strategy that not only positioned him as the champion of the free market against Keynesianism but also endowed the Austrian school with a distinctive character and challenged the relevance of general equilibrium theory and associated mathematical techniques. ${ }^{4}$ Hayek attacked directly the core idea of equilibrium, without which mathematical modeling would be pointless. $\mathrm{He}$ argued that markets worked not because they reached equilibrium, but precisely because they never did (since the point of equilibrium is also a point of zero profits and least motivation). Consequently, "it becomes exceedingly difficult to say what are exactly the assumptions on the basis of which we assert that there will be a tendency towards equilibrium and

${ }^{4}$ While Keynes was not particularly partial to mathematical economics, already by 1937 Hicks translated Keynes's general theory into an influential mathematical version, which became the basis for the postwar dominant coalition composed of mathematical modelers, Keynesians, and econometricians (Yonay 1998, pp. 190-95). Hayek was probably responding to this synthesis. 
to claim that our analysis has an application to the real world" (Hayek 1948, p. 48). The advantage of markets lay rather in the fact that they provided dispersed, accurate, real-time information, coupled with precisely calculated incentives, in a way that allowed economic actors to "coordinate" their decisions and actions. The fiction of the Walrasian auctioneer was thus a distorted representation of the economic process; consequently its equation with the position of a central planning office was illegitimate. Neither could the central planning office know all that is needed in order to adjust prices accurately, nor could it calculate and communicate the new prices in real time to economic actors. Hayek thus challenged the relevance of the Walrasian representation of equilibrium to the understanding of market processes and sought to push mathematical technique back to the status of a fictitious model of limited heuristic value.

Socialism was thus, for Hayek too, a privileged laboratory for economic knowledge. While one could apply general equilibrium theory to capitalist market relations and argue that it served as a good enough approximation, in the socialist laboratory it was possible to open up the black box and untie the chain of assumptions underlying the model. In particular, the attempt to "program" economic relations highlighted their character as information relations and raised the problem of how economic actions are to be coordinated in real time and under conditions of limited information. As Hayek himself testified, this new conception of markets was not simply a matter of self-clarification, making explicit what was already implicit in the Austrian tradition, but a result of the debate about socialist economic calculation, made possible by the socialist laboratory experiment:

It was only when, because the economic system did not accomplish all we wanted, we prevented it from doing what it had been accomplishing, in an attempt to make it obey us in an arbitrary way, that we realized that there was anything to be understood. It was only incidentally, as a by product of the study of such isolated phenomena, that it was gradually realized that many things which had been taken for granted were, in fact, the product of a highly complicated organism which we could only hope to understand by the intense mental effort of systematic inquiry. (Quoted in Shearmur 1996, pp. 36-37)

It is important to recognize how precarious Hayek's new conception of markets and coordination was and how completely it depended on the socialist laboratory to demonstrate its advantage over competing versions of neoclassical economics. Hayek criticized general equilibrium theory and mathematical modeling for their lack of realism, but without the comparison to socialism his own approach did not seem any more realistic. 
Unlike equilibrium, for example, coordination was not a mathematically formalizable property of markets, but neither was it an empirically observable property. Hayek, who called for economic theory to pay attention to how markets "actually worked," could not himself explain how to observe such workings, nor could he prove that coordination was produced by the mechanisms he claimed were producing it—private property, price signals, and profit and loss calculations (Shearmur 1996, pp. 50-52). Moreover, he was loath to recommend concrete empirical investigation of institutions because Austrian economics was formed by championing theoretical analysis as against the German historical school (Yonay 1998, p. 39). This is why the socialist laboratory was of such crucial importance for the coherence of the Austrian school, equipped, however, with a different translation strategy than the one deployed by mathematical economists. This translation strategy was formulated beautifully, many years later, by a Czech economist: "[Socialist] countries represent a sort of laboratory, unique for economists, not too different from a high-energy laboratory used by physicists, where phenomena which are manifest under normal conditions as tiny deviations, achieve large magnitudes; it is then easier to study the laws of their development" (Zieleniec 1990, p. 8).

This translation strategy did not construct a relation of formal equivalence between the socialist laboratory and capitalist market relations, but an almost opposite relation. If, for the Walrasian, formal equivalence lay in the fact that markets were nothing but a collection of programming problems, for the Austrians the possibility of translation lay in the fact that central planning was nothing but submerged, distorted, and subordinated markets - that is, the inescapable relations of information. The study of socialism thus served as a laboratory experiment meant to determine "how far one can go in introducing command elements into a market economy" (Friedman 1981, p. 3), that is, to translate socialist economic phenomena into large-scale distortions of markets corresponding to the "tiny deviations"-principal-agent problems, monopolies, supply constraints, imperfect prices, shortages, inflation—supposedly introduced by Keynesian state intervention. Using this translation strategy, Austrian economists could mobilize the results obtained in the socialist laboratory to criticize the institutional design of Western capitalism and to highlight by contrast the capacity of markets to provide accurate in-time information and to effectively coordinate individual action (Hayek 1939, pp. 9-10).

A reader well versed in neoliberal economics can recognize here a point common to many later strands of economic analysis: public choice theory, monetarism, information economics, property rights theory, and, in general, the contemporary obsession with "governance." It was not our intention, however, to argue that neoliberalism sprung from Hayek's head, 
fully formed and clad in shining armor. Our argument is that the socialist calculation debate constituted an important discursive event in the history of neoliberalism by constituting socialism as a laboratory of economic knowledge. While the realization of laboratory "experiments" in socialist Eastern Europe and the Soviet Union would emerge later, this debate provided the resources for interpreting and translating them.

But in order for this discursive event to have the effect it eventually did, the socialist laboratory had to be connected by strong and permanent ties to debates in Western economics. In this section, we merely highlighted the two competing strategies of translation brought forth in the course of the debate, each attempting to mobilize the results obtained in the laboratory and make them count in Western economics. In the next section, however, we will consider the forging of transnational ties between American and East European economists in two competing networks: the larger and more established one based on the neoclassical translation strategy of formal equivalence, and a smaller network, somewhat parasitical on the first, based on the Austrian strategy. In the third and last section, we will show that this latter translation strategy served to align the interests of the American and East European economists who formulated the blueprints for market transition in 1989.

\section{EAST-WEST DIALOGUE DURING THE 1950s AND 1960s}

To translate and mobilize the results obtained in the socialist laboratory into arguments about market relations, economists needed to build transnational networks. While the goal of our analysis is to demonstrate how neoliberalism was put together by a transnational network organized around the Austrian translation strategy, the story must begin elsewhere. Throughout the 1950s and 1960s, by far the larger and more consequential network was the one organized around mathematical economics and the translation strategy of formal equivalence. This network was constructed with the support of the U.S. government and American philanthropic foundations, which were interested in establishing East-West dialogue as a means of fighting the cultural Cold War. Neoliberalism, on the other hand, was constructed within a secondary network, usually without official support, and typically parasitical on the confidences established by the primary one.

There were three interrelated efforts of the U.S. government and American philanthropic foundations, which provided the infrastructure for transnational dialogue. First, the U.S. government provided funding for mathematical economics, which quickly established the operational details of the very form of planning outlined by Lange. U.S. government officials 
became convinced of the usefulness of mathematical economics during the Second World War. In the process of solving military distribution problems, George Dantzig and later Tjalling Koopmans developed linear programming. They brought these techniques to the military consulting agency, RAND, and to the Cowles Commission, which became centers of quantitative analysis. Also as part of the war effort, John von Neumann and Oskar Morgenstern had developed game theoretic analyses of economic questions, and Wassily Leontief applied his recently developed input-output analysis to find a solution for the problem of labor reallocation after the war. Mathematical economics became the center of a hegemonic coalition-composed of mathematical economists, econometricians, and Keynesians-dominating American economics. They were united by an interpretation of the Great Depression as proof that markets required state intervention in order to function efficiently and by the translation strategy of formal equivalence between markets and planning. Linear programming, for example, was interpreted as a demonstration that, under specified conditions, the results of market transactions and planning directives were mathematically equivalent. This interpretation of mathematical technique, as well as the bias toward some form of planning, made this field particularly suited for an East-West dialogue (Bernstein 2001; Kelley 1997, p. vii; Morgan 1990; Morgan and Rutherford 1998; Poundstone 1993; Weintraub 1985; Yonay 1998, pp. 184-95).

Second, many American economists answered the Cold War call to study the Soviet Union and Eastern Europe, which led to the emergence of the field of "comparative economic systems," which was funded by government and foundation money. Throughout the country, centers for the study of the Soviet Union and other regions opened, most notably the Russian Institute at Columbia University in 1946 and the Russian Research Center at Harvard University in 1947 (Cummings 1998; Fisher 1959; Fleron and Hoffman 1993; Gleason 1995; Robin 2001). The opportunities for funding and positions in the area of Sovietology, as well as the apparent economic success of the Soviet Union, created much interest in research on comparative economic systems. We should emphasize, however, that the field of comparative economic systems was larger than Sovietology per se. Some American academics interested in studying Soviet planning were not Sovietologists but mathematical economists who found in Soviet planning an important site to test their tools (Prybyla 1969, p. viii). If mathematical planning furnished a common language for East-West dialogue, federally funded research on comparative economic systems incorporated this language within a research program capable of translating East European data into theoretical advancements in the study of capitalism.

Third, such a dialogue was actually conducted within the framework 
of East-West academic exchanges sponsored by the U.S. government and American foundations. After Stalin's death in 1953, the U.S. and Soviet governments, as well as those of Eastern Europe, negotiated new forms of contact, including academic exchanges, which each side sought to use for its own Cold War purposes. ${ }^{5}$ U.S. government officials saw academic exchange as a means of undermining socialist regimes by infiltrating the closed, totalitarian states with American ideas and values (Barghoorn 1960; Raynor 2000, p. 101; Sutton 1987). Economics in particular were considered a "gateway science" that could lead to broader economic and political discussions. Policy makers were "hoping that consideration of individual preference in markets and prices eventually could lead to similar attention to individual preferences in political selection." ${ }^{\prime 6}$ Academic exchanges included long- and short-term research and teaching visits. Sovietologists and practitioners of "comparative economic systems" studying socialist economies constituted the largest group of economists involved in academic exchanges, but there were also many others interested in linear programming and mathematical planning tools and the usefulness of East European economies as another case in their research. The latter were particularly instrumental in creating another form of EastWest dialogue, namely East-West conferences that included roughly equal numbers of participants from capitalist and socialist countries. These conferences increased in number from 1961 onward and usually were organized around some aspect of mathematical planning. The largest EastWest conferences were the input-output congresses organized by Wassily Leontief and his colleagues at Harvard University. These congresses took place every few years. By 1970, the congress in Novosibirsk in the Soviet Union brought together thousands of participants. Similarly, the International Institute for Applied Systems Analysis (IIASA) at Vienna was created to serve as a place where American and Eastern European scholars could work together, on a long-term basis, on common problems such as econometric modeling, management issues, and world climate change. ${ }^{7}$

\footnotetext{
${ }^{5}$ While some American academics traveled to the Soviet Union and Eastern Europe soon after 1953 on one-month tourist visas, the first American academic exchange agreement was signed with the Soviet Union in 1958. The Ford Foundation established exchanges with Poland in 1957, Yugoslavia in 1959, Hungary in 1962, Romania in 1965, Czechoslovakia in 1968, and Bulgaria in 1968. See Byrnes (1976) and Richmond (1987).

${ }^{6}$ Ford Foundation archives, reel 2346/grant no. 64-432; letter from Earl O. Heady at Iowa State University to Shepard Stone at the Ford Foundation, April 20, 1965, p. 2.

7 Johnson and Kennedy administration officials, the Ford Foundation, RAND, and the U.S. State Department developed the rationale and organization of IIASA, which was envisioned as encouraging the communication of scientists and creating a form of détente, as well as undermining socialism. See Ford Foundation archives, Industrial Societies Project box, as well as reels R-2679 and R-2680.
} 
American Journal of Sociology

Numerous smaller scale meetings also took place, such as the East-West Conference on Economic Decision and Planning Models for Agriculture that Earl Heady started in 1967 with 39 economists from East and West. ${ }^{8}$ The International Economics Association also sponsored small-scale EastWest meetings, such as the "labor productivity" conferences organized by John T. Dunlop, Abram Bergson, and Walter Galenson in 1961, which continued annually with about 30 participants. These conferences had lasting affects. Almost every conference resulted in an edited volume, thus providing the opportunity to further the exchange of knowledge generated by these events. Many economists maintained correspondence with their colleagues in Eastern Europe, which included discussions of ideas and techniques as well as the exchange of articles and books. American scholars found it easy to send books because, upon request, the CIA would purchase and send books in any scholar's name to individuals in the East Bloc.

Such was the infrastructure of Cold War-era dialogue between East and West. Its common language, as well as numerous research programs, was provided by mathematical economics, in particular anything pertaining to mathematical planning. Academic exchanges and conferences allowed the construction of a transnational network of economists. But why were the two sides interested in this dialogue at all? And how were their interests translated and aligned?

Contrary to popular belief, East Europeans who participated in academic exchanges and conferences were not necessarily "party hacks," but highly regarded scientists and academically oriented policy makers. East European economists had a great interest in mathematical economics, linear programming, and econometrics for professional, political, and personal reasons. During the 1950s and 1960s, from Stalin's death to the Prague Spring and the launching of the "new economic mechanism" in Hungary, most East European regimes witnessed a continuous struggle between hard-line Stalinist factions in power and anti-Stalinist reformers seeking to take their place. The reformers supported a group of economists who argued for market reform and the decentralization of planning. They also argued for the use of mathematical economics, linear programming, and econometrics because these techniques allowed economists to create an area of ideologically neutral economic discourse that would take place under the jurisdiction of the profession. The reformers thus wielded a powerful discourse of technical expertise with which to challenge their opponents. In return, whenever they gained a foothold in power, the antiStalinists provided these economists with professional institutions, re-

${ }^{8}$ Ford Foundation Archives, letter from Gordon to Stone, January 3, 1967, East-West Conference on Economic Decision and Planning Models for Agriculture. 
sources, political protection, and influential positions in state and party economic institutions. In this way, the cause of political reforms, the idea of market socialism, and the delineation of an area of technical economic discussion protected from ideological accusations were bundled together in one politico-professional project. Put differently, the project of "reform economics" was at once a drive for political reform and for professionalization (Bockman 2000). Mathematical economics and mathematical planning were crucial components of this professional project because their highly formal nature made it easier to present them as outside the realm of ideology and because linear programming and similar techniques implied the possibility of a middle road between markets and central planning, which was homologous with the aim of the reformers in the political sphere. Thus, the East-West dialogue and its resulting network could bolster the professional and political projects of at least a large fraction of East European economists.

The strategy of formal equivalence served to translate these interests and align them with those of Western economists who participated in the dialogue. John Kenneth Galbraith recalls that, during his 1958 trip to Poland, "at dinner one economist, another agreeing, made an impressive point. He said, 'We have argued against our more orthodox colleagues that there can be sustained growth under capitalism. Now with the recession we already hear it said that we were wrong. Do you realize what a test this is for your economy-and for our reputations?"' (Galbraith 1958, p. 72).

Formal equivalence meant that the professionalization project of East European economists, as well as the reformers' struggle against the hardliners, could be translated and aligned with the interests of Western economists who were champions of Keynesianism and mathematical economics. This translation served as the basis for a highly advantageous exchange between the two sides. First, the academic exchanges organized by the Ford Foundation provided East European economists with money, resources, and time to conduct research. ${ }^{9}$ Second, and even more important, the exchanges provided grantees with a crash course of immersion in the American economics profession. Most participants visited the United States for a 10-month period. They gained firsthand experience

\footnotetext{
${ }^{9}$ See the appendix for a list of names and titles of Hungarian economists who participated in Ford Foundation exchanges from 1964 to 1969. Many Polish and Yugoslavian economists also participated in Ford Foundation exchanges in this period. We would like to underline the point that almost all of the individuals listed were not known as "party hacks," but as reform economists, some of whom went ahead to play a major role in reformist politics. Unless otherwise indicated, this information came from the Ford Foundation archives and final reports written by grantees. See Ford Foundation Archives, reels 2346 and 2347 .
} 
with the American university system through affiliation with one or two top-ranked universities, primarily Harvard, but also the University of California at Berkeley and at Los Angeles, Stanford, MIT, and others. In addition to studying intensively at their affiliated universities, they also visited numerous campuses throughout the country. They went to seminars, gave lectures, and worked with professors. Third, they acquired new skills_including computer programming and input-output modeling-as well as books, periodicals, newspapers, and economic data, all of which they brought back home with them. ${ }^{10}$ Fourth, they developed social ties and social skills (in particular improved English language skills), which made further exchanges significantly easier and more regular. Grantees attended professional meetings, such as those of the American Economic Association, the American Statistical Association, and the Econometric Society. They also received a two-year subscription to a journal of their choice when their exchange year ended. When they returned from exchanges and conferences, grantees could use their personal contacts in the United States to obtain more books, journals, and data. They could use the international prestige of their Western colleagues, especially Nobel laureates, to support careers at home and obtain invitations for future visits to the United States. These personal contacts improved the economists' professional work environment and provided alternative sources of funding and recognition. ${ }^{11}$

In return, their Western colleagues could use these exchanges to forge ever more extensive actor-networks and to mobilize the work of distant participants. Formal equivalence meant that they could interpret their transactions with East European economists as reinforcing the universal nature of their models. This alignment of interests also entailed a particular division of labor. American economists occupied an "obligatory point of passage" within the network, controlling the flow of resources to colleagues around the world and concentrating the results of their work in their hands. The whole translation and alignment of interests depended on "black boxing" the work going on in Eastern Europe and interpreting

\footnotetext{
${ }^{10}$ Western economic texts inclusive of Adam Smith and Keynes were by no means unavailable and a restricted group of experts could use them. The use of Western literature has been obscured by the fact that most economists did not cite it for fear of political persecution. Egon Balas (2000), e.g., a Romanian mathematical economist, remembered meeting Hungarian economist, Tamas Nagy, who told Balas to not cite Keynes but to present Keynes's ideas in his own name. The extensive use of Western texts has been measured, though problematically, through scientometric studies of citations. For the case of Hungary, see Such and Tóth (1989).

${ }^{11}$ As János Kornai remembered, "the regime in Hungary did follow what was happening to me, so they knew of my foreign acceptance and reputation, which widened my opportunities for writing" (Blanchard 1999).
} 
the contributions of East European economists as simply "data," the "facts" about another interesting, yet formally equivalent case. The story of Wassily Leontief exemplifies these processes. Leontief was born in Russia before the revolution, studied economics in Russia, and completed his graduate work in the 1920s in Germany, where he began to develop his input-output analysis. As a professor at Harvard University from the 1930s, Leontief participated in all three interrelated efforts of the Cold War mentioned above. ${ }^{12}$ He obtained federal financing to develop an input-output model for analyzing the problem of labor reallocation. $\mathrm{He}$ was also a key player in the emerging field of "comparative economic systems," as a founding member of the Russian Research Center. He argued that his input-output analysis was applicable to any economic system. It was a tool that allowed one to evaluate the relative efficiency of economic systems. Finally, he organized East-West exchanges and conferences with the particular vision that input-output analysis could provide a common language across the Iron Curtain. In 1959, he traveled with a Harvard University delegation to Moscow to initiate an exchange program there. In the early 1960s, he actively supported the formation of an institute for East-West discussions, which later became IIASA. Moreover, he maintained an extensive correspondence with East European economists, sending them articles and books through the CIA. He included their articles in his edited volumes, and he invited them and many others from around the globe to his input-output conferences, as well as to visit and to work with him at Harvard.

While he generally viewed these transnational interactions as having a positive role promoting world peace, Leontief also placed himself as an obligatory point of passage within this transnational network. Leontief had a specifically scientific interest in creating transnational linkages because he sought to build a world input-output model, expanding from his original model limited to "only" the American economy. For that purpose, he needed to mobilize a vast group of economists and other experts from around the globe who could construct their own input-output tables. This required technical instruction in making these tables, but also the standardization of national economic data worldwide, as well as improvements in computer processing speeds. ${ }^{13}$ As a result of his continual in-

\footnotetext{
${ }^{12}$ The following information about Leontief came from documents in the Wassily Leontief papers at the Harvard University archives.

${ }^{13}$ Leontief's ideas about world modeling can be found in Leontief (1977). By 1968, input-output models had been constructed for more than 50 countries and applied to hundreds of specific problems (Chenery 1970). In March 1968, the UN adopted a new system of national accounts (SNA), revising those from 1952. In the new system of standards, input-output data was integrated into the new system (Aidenoff 1970). A critical analysis of the world modeling movement can be found in Ashley (1983).
} 
ternational networking, Leontief made input-output modeling a very successful enterprise by the 1960s. He received an enormous number of requests for consultations with both government agencies and companies. ${ }^{14}$ As he forged an ever-more-international network, he bolstered his own position at its center. His office in Harvard was an obligatory point of passage for money, data, and other resources used by input-output analysts and by the same token the site where the work of foreign economists was mobilized, translated, and accumulated as "data," or as further proofs of a universal model. Thus, while we would argue that inputoutput analysis is a good example of a transnational network, his own status as an obligatory point of passage allowed Leontief to declare that input-output modeling was an approach to economics that "originated in the United States" (1963, p. 101).

This capacity to position oneself as an obligatory point of passage, we argue, was responsible for the fact that these Cold War-era transnational networks were typically forgotten or their significance minimized. The network structure thus created mobilized the work of East European economists, while translating and aligning their interests, but at the same time obscured its own functioning because such contributions were seen as merely "data" or reports from direct "experience," rather than the production of economic knowledge. We found many informal reports by American participants in exchanges and conferences that testified to their continual "amazement" at how well-versed in mathematical economics their East European colleagues were. For example, when Leontief traveled to Moscow in 1959, still before he launched his international inputoutput conferences, he was surprised to find the widespread use of inputoutput analysis, the publication of his books, and a large, developed group of input-output modelers (Leontief 1963). Nonetheless, such "discoveries" were interpreted as the exception that proved the rule. American economists assumed that East European economic knowledge was nothing but the ideological charade of Marxist-Leninist political economy. As a result, the contributions of East European economists were accepted as merely facts about Eastern Europe gained through direct experience and thus as powerful independent proof of Western economic science. Writing about mathematical economics in the Soviet Union, Robert Campbell, for example, found Russian economists using utility functions similar to those developed in Western economics. He did not, however, think that they found these in Western textbooks, but that these functions were developed from the experience of central planning, which thus served to empirically

\footnotetext{
${ }^{14}$ These numerous requests can be found in Leontief's papers, Harvard University archives.
} 
and independently verify the truth of these utility functions. ${ }^{15}$ One can see how the translation strategy of formal equivalence permitted Campbell to construe this similarity not as a result of scholarly communication and network ties, but as an experience gained by trying to solve the same essential problem through "trial and error," just as Lange recommended.

We find, therefore, that mathematical economics was the common language of an institutionalized form of East-West dialogue during the Cold War period and that this dialogue was both permitted and obscured by the translation strategy of formal equivalence and by the positioning of Western economists at obligatory points of passage within the network. This translation strategy aligned the interests of East European economists, who used these contacts in their combined drive for economic reform and professionalization, with those of their Western colleagues, who mobilized them as "data" to bolster the universal applicability of their models.

Alongside this dominant network of exchanges, however, there was another dialogue conducted between Western libertarian economists and some of their East European colleagues. Here, again, a similar alignment of interests developed, though now governed by the Austrian translation strategy. The American market libertarians sought out their East European colleagues, within the framework of existing East-West exchanges and conferences, in order to enlist their support in the battles they had to fight back home against the Keynesian orthodoxy. The Austrian translation strategy permitted these economists to use the knowledge produced by their East European colleagues as evidence from laboratory experiments, which proved, under controlled conditions, the bankruptcy of the remedies, policies, and thinking of their Keynesian opponents. As we shall see in the next section, however, their Eastern European interlocutors were interested in the exchanges with the libertarians because they were engaged in battles over professional jurisdiction and market reforms and because in the course of these struggles they too used the Austrian translation strategy to undermine and discredit their opponents. Hence what

\footnotetext{
${ }^{15}$ Campbell (1963) discusses the work of A. A. Konius, who attempted to find the proper relationship between the prices of consumer goods, and the labor inputs used in their production, with the aim of minimizing the total labor input. He argues, "Incidentally, Konius' question is not one made up in the quiet of the professor's study but one that has long agitated those who plan the prices of consumer goods in the Soviet Union. The answer given by Western economists to this question appears in every elementary economics textbook as "prices should be proportional both to the marginal rates of substitution and the marginal rates of transformation of the goods in question.' Not being accustomed to consulting this kind of source for answers to questions of socialist political economy, Konius enlisted the aid of a professor of mathematics (duly thanked in a footnote) and worked out the answer himself. Not surprisingly, he came to the same conclusion" (p. 117).
} 
the Americans mobilized as "evidence" from laboratory experiments cannot be separated from the rhetorical strategies deployed by radical reformers in Eastern Europe. Neoliberalism, as we know it, developed within this East-West dialogue and traveled back to the United States through transnational networks, eventually to become hegemonic.

In the 1950s and 1960s, libertarians were a distinct and embattled minority among American economists, mostly concentrated in the University of Chicago (Kelley 1997; Stigler 1988). Chicago-trained economists also created centers of libertarian thinking in the University of Virginia and the University of California, Los Angeles. Frank Knight, Milton Friedman, and others at Chicago were engaged in on-going battles within the economics profession against the Keynesians and mathematical economists particularly at the Cowles Commission. Being a minority within the American economics profession, libertarian economists sought refuge in international libertarian associations, most importantly the Mont Pelerin Society, with the financial support of conservative foundations (Cockett 1995; Friedman and Friedman 1998; Kelley 1997). ${ }^{16}$ Even more important, for our purposes, were a series of East-West conferences in Italy running from 1965 to the mid-1980s. These conferences were organized by Renato Mieli, who had been a high-level Italian Communist Party leader, but left the party after 1956 and ran a think tank in Milan called the Center for the Study of Economic and Social Problems (Centro Studi e Ricerche su Problemi Economico-Sociali, or CESES). Mieli was well connected in Eastern Europe and knew many leading economists. At the same time, he became integrated into the emerging American libertarian network through Warren Nutter, an economist from the University of Virginia and former student of Milton Friedman. ${ }^{17}$ American conservative organizations funded both the conferences and a summer institute for American and Italian graduate students. These meetings focused on the problems of socialist economies and the nature of economic reforms in Eastern Europe. Some of the conferences were titled "Prices and Economic

\footnotetext{
${ }^{16}$ In 1947, a small group of libertarians met in Mont Pelerin, Switzerland, to create an association that would allow like-minded scholars to speak freely and to develop libertarian ideas. This view of the Mont Pelerin Society as a refuge from daily attacks is very clear in Hartwell (1995). See also Friedman and Friedman (1998, pp. 159, 333). Conservative foundations funded both Hayek's position in Chicago and Mises' position at New York University (Friedman and Friedman 1998, p. 161; Kelley 1997, pp. 62, 64).

${ }^{17}$ On his 1967 and 1969 trips to the United States, Renato Mieli met also with William J. Baroody, Sr. (president of the American Enterprise Institute), Richard Ware (director of the Earhart Foundation), and other right-wing leaders. William J. Baroody, Sr., Papers, Library of Congress (LOC), box 79, folder 11, Organizations File, American Enterprise Institute, Scholars and Fellows Program, Nutter, G. Warren, 1966-67; and box 88, folder 5, Organizations File, CESES (Renato Mieli), 1969-79.
} 
Reform," "Investment Policy," and "Managerial Incentives in East and West." In general, the conferences took place in luxurious villas in Italy, which allowed for enjoyable formal discussions, as well as private talks around the pool or at dinner. ${ }^{18}$

One could interpret the CESES meetings one-sidedly, as American neoliberals indoctrinating socialist economists in the new truth. Similarly, one could view them as preaching to the converted, as the East European economists already were convinced of the bankruptcy of communism and were neoliberals at heart. However, participants actually represented a broader range of political views, from Western market socialists such as Alec Nove to staunch libertarians such as Milton Friedman. At least one American participant, who had not known who the American organizers were, found Friedman to be "so purely right wing" and not in line with the rest of the Western participants. ${ }^{19}$ The essential fallacy is to project backwards this contemporary label-neoliberalism-that has a fairly wide, and somewhat fuzzy, classificatory purchase. The American participants were not neoliberals per se, but rather libertarians, namely they shared a negative agenda being antistate, antiplanning, and anticommunist, but not a well-defined positive agenda of economic theory. The East European economists too were not neoliberals, but rather reform economists or market socialists, who sought to incorporate markets into a planning system. In the 1960s, this was clearly the agenda of Hungarian reformers such as Janos Kornai and Tamas Nagy, who participated in CESES meetings. "Neoliberalism" is precisely what became possible through these meetings, wherein these two distinct sets of interests were aligned by means of the Austrian translation strategy and on the common ground provided by the laboratory of reform socialism.

In the next section, we discuss the interests of the East European economists and how they were translated and aligned. For the moment, we shall concentrate on the group of American libertarian economists. They were sincerely interested in dialogue with East European economists because they believed that in this way they were working to undermine

\footnotetext{
${ }^{18}$ Between 1967 and 1973, of the 257 participants in the conferences, 93 were from Eastern Europe and the Soviet Union. A large part of the 257 participants were from Italy because the conferences were usually in Italy and the Italian founders wanted to focus on teaching Italian academics about East European economies. Between 1967 and 1975, of the 37 lecturers in the summer institute for graduate students, 23 of them were from Eastern Europe. Here, 98 American graduate students participated in the institute, while similar numbers or more Italians participated. William J. Baroody, Sr., Papers, LOC, "Program for Academic Communication and Exchange," Thomas Jefferson Center Foundation, June 16, 1975, annex B, C, D.

${ }^{19}$ Confidential interview conducted April 11, 2001, with an American economist who participated in the CESES meetings.
} 
socialism. No less important, however, the Austrian translation strategy meant that they also interpreted these exchanges as promising to bolster their own weak position back in the United States. To translate their interests in this way, however, libertarian economists had to construe East European economists as outsiders to Western debates, unfamiliar with Western literature. Thus, Milton Friedman remembered one of the CESES meetings, where they "heard a brilliant talk by a Hungarian Marxist economist. He had rediscovered for himself Adam Smith's invisible hand" (Friedman and Friedman 1998, p. 338). This move permitted them to scrutinize the discourse of East European economists in a way not possible when dealing with Western colleagues and to open the "black boxes" of which this discourse was composed. American libertarians then divided East European discourse into two parts: one intelligible, and the other redundant. The intelligible part consisted of "the facts" about socialist economies. While incompetent in matters of theory, the East European economists were presumed competent in regards to the empirical realities of their own socialist economies. Hence, one could treat their discourse as a credible report on reality, rather than controversial theoretical propositions. The redundant part was composed of ideological rhetoric. East European economists had to use a form of coded language in order to protect themselves from the communist authorities back home. This part of their speech could be disregarded altogether. Thus, in 1967, after meeting an East European economist in a CESES conference, a right-wing foundation leader told Warren Nutter that "it was our feeling that his idea of reform was still a very long way from advocating a free market system." Nutter replied that East Europeans had to speak in an "Aesopian language": "Those who are accustomed to participating in such exchanges learn to recognize the key words in this coded language and to respond with appropriate key words until rapport is established. ${ }^{20}$ Nutter thus indicated that some parts of the speech of East European economists should be disregarded; the rest could only be conveyed through the mediation of competent interpreters, such as libertarian economists.

As a result, Nutter and the libertarians obscured the fact that East European economists, particularly those who attended such conferences as CESES, had long had access to Western literature and had long debated the nature of socialism and the necessary reforms with Western colleagues in similar forums. As we shall see in the next section, these economists were neither reporting merely the facts, nor was their true vision of reform masked by coded language. But such representations allowed American

${ }^{20}$ William J. Baroody, Sr., Papers, LOC, letter from Donald A. Collins, T. Mellon and Sons to Warren Nutter, May 9, 1967; William J. Baroody, Sr., Papers, LOC, draft confidential letter from Warren Nutter to Donald A. Collins, May 11, 1967. 
libertarians to use East European economists as "naïve witnesses" reporting from inside the black box of mathematical planning and thus to take it apart. According to Nutter, who attended the 1966 conference:

It was readily apparent that the Eastern participants were more eager to hear from Western supporters of the market than from Western sympathizers of socialism. They have nothing to learn from the latter and in fact have something to teach them. The views of Western advocates of central planning must appear naïve, indeed, to those so experienced in its actual workings. ${ }^{21}$

Through this perception of East European economists, American libertarians could mobilize East European contributions and turn them into weapons with which to fight their own battles in the United States. The final step in this mobilization was to translate the East European critique of planning, via the Austrian translation strategy, into a large-scale laboratory experiment demonstrating the failures of Keynesian state intervention: "Another way to illustrate the role of market systems is to describe problems arising from experiments with administrative controls in communist countries. Even though these countries have succeeded in generating economic growth, they have also been confronted by very much the same problems that are generated by price controls in capitalist counties, though of course on a very much larger scale" (Lindbeck 1971, p. 40). ${ }^{22}$

To effect this translation, the libertarians brought Mieli and East European economists to the United States to meet with foundation directors and to give talks at university departments. Nutter argued that "such visits would have an important educational value for Westerners as well as Easterners. I can think of no more effective antidote to the current dirigiste mentality of academia than the message of these scholars from

\footnotetext{
${ }^{21}$ William J. Baroody, Sr., Papers, LOC, confidential memorandum to W. J. Baroody and others from G. W. Nutter, Subject: CESES Seminar, Florence, September 14-16, 1966. September 29, 1966, p. 4. Others, such as Turgeon (1971) and Portes (1983), did notice that the East Europeans were using "right-wing" ideas, rather than merely reporting the facts.

${ }^{22}$ Compare an even stronger formulation by a later adherent of Austrian economics and observer of the rise of neoliberalism: "Probably the most significant self-criticism on the Left has come from Eastern Europe, where the failures of socialist policy are closest at hand, and where the first murmurings of a wholesale rejection of planning by radical intellectuals were heard. It is in Eastern Europe where 'conservative' means 'defender of central planning' and where 'liberal' means 'proponent of decentralized market institutions.' It is there where the stirrings of a grassroots radicalism that fundamentally objects to the whole idea of planning are to be found" (Lavoie 1985a, p. 235).
} 
Eastern Europe. ${ }^{23}$ They expected a similar effect from sending American graduate students to Europe, to be "taught by the strongest critics of planning: economists from Eastern Europe." ${ }^{24}$ The libertarians construed their East-West exchanges as working toward two, mutually reinforcing goals: fomenting resistance to Communism in the East and translating it into a transformation of hearts and minds in the West:

I know of few activities with greater potential payoff for a relatively tiny investment than the conferences and contacts now being arranged through Mieli. In many respects, the hope of the West lies in the East. The best prospect for halting the plunge of the West into collectivism is revolt against communism in the East. It would be romantic to expect any single activity to move the course of history, but drops of water can wear away stone if properly concentrated. ${ }^{25}$

Indeed, post hoc, American libertarians have reinterpreted the CESES meetings as part of a vast libertarian network that successfully revolutionized the world. According to Friedman and Friedman (1998), for example, Mieli created CESES precisely in order to promote free-market ideas (p. 338). What is missed, however, by presenting CESES as merely one in a series of libertarian institutions dedicated to the same goal-the Mont Pelerin Society, the Philadelphia Society, American Enterprise Institute, Volker Foundation-is the fact that the transnational dialogue reshaped both sides. It was not so much part of a successful libertarian conspiracy to topple communism and Keynesianism in one blow, but the breeding ground for the new hybrid discourse of neoliberalism, which was being created through the process of translating, on both sides, the knowledge produced by participants and mobilizing it to travel back to United States, to fight the wars of deregulation, and back to Eastern Europe, to fight the wars of reforming socialism. At the same time, this process of translation and mobilization was marked by the unequal structure of the transnational network, in which Western economists formed obligatory points of passage and mobilized East European knowledge as data bolstering the universal applicability of their models. Nonetheless, it is these hybrid and dialogic origins of neoliberalism, rather than the arrogance and might of a Western monologue, that helps explain the

${ }^{23}$ William J. Baroody, Sr., Papers, LOC, confidential memorandum to W. J. Baroody and others from G. W. Nutter, Subject: CESES Seminar, Florence, September 14-16, 1966. September 29, 1966, pp. 5-6.

${ }^{24}$ G. W. Nutter, undated [1975], draft paper, p. 2; William Baroody, Sr., Papers, LOC, box 80 , folder 2 .

${ }^{25}$ William J. Baroody, Sr., Papers, LOC, confidential memorandum to W. J. Baroody, Sr., and others from G. W. Nutter, Subject: CESES Seminar, Florence, September 1416, 1966; September 29, 1966. 
course of the radical and rapid transition to capitalism in Eastern Europe, once communism fell.

\section{THE WASTELAND}

When, after the revolutions of 1989, Western advisors arrived to Eastern Europe, they reported back home that they found the economies of the region in shambles. They discovered a world upside down, where the rules of economic rationality were ignored, and the expert eye discerned a vast wasteland of atrophied industrial growth, distorted price and incentive structures, shortages, and rent-seeking. They concluded that radical surgery was needed to remove the ruins of communism, create a blank slate, and reconstruct economic institutions from scratch: "Because the party was the state, the state collapsed from the top when the party fell and a great void opened up. This suggests a great opportunity because of the amount of destruction" (Aslund 1992, p.16; see also Lipton and Sachs 1990).

Western economists believed that they were bringing a new worldview, knowledge, and practice to this blank slate of Eastern Europe. As we now know, however, East European economists had been participating in East-West dialogues about markets and planning for decades. Within these transnational networks, the interests of Western and East European economists were translated and aligned as the latter used the resources provided by the former to fight for professional jurisdiction and political clout, while Western economists had imported East European knowledge into the United States as "facts" and as undeniable proof of their universal models extracted from the laboratory of socialism. We argue that the rapid adoption of neoliberalism in Eastern Europe after the fall of communism was simply another instance of this translation and alignment of interests. Western economists' diagnosis of East European economies as wastelands, for example, did not reflect the economic situation as they found it, but the assessments conveyed to them by East European reformers and economists. It was another case where the knowledge produced by East European economists was construed as simply a report on the "facts." Let us be clear: we are not arguing whether this diagnosis was correct or whether it accurately reflected economic reality. ${ }^{26}$ Our point is simply that the social genesis of this diagnosis, as well as the prescription of "shock therapy," should not be sought in the arrogance of Western advisers, but

\footnotetext{
${ }^{26}$ Moreover, we would argue, with Jessop (1999), that "economic crises involve more than a final encounter with pre-given structural limits. They are manifested and resolved in an inter-discursive field ... through which social forces assert their identities and interests" (p. 396).
} 
American Journal of Sociology

in the discourse developed by East European reformers and economists, who in the course of successive attempts at reform, and in the context of transnational network ties with Western libertarians, have developed a vision of the socialist economy as chaotic, inefficient, and in need of shock therapy. Such a vision was neither simply true nor false, but it was certainly partial, taken as it was from a particular corner of the social field and reflecting the experiences of one specific contender in the struggles over the reforms. Moreover, this was an influential vision: the East European economists we quote here-Balcerowicz, Gaidar, Klaus, Kornai, Yavlinsky-were all-powerful political actors during the transition, ranging from special advisers through finance ministers to prime ministers.

At least three independent factors interacted to create this vision and to steer it in the direction of such a radical diagnosis and prescription: (1) the "push" factor provided by the on-going struggle over successive attempts at economic reform, (2) the "pull" factor provided by the growing attraction of the dissident discourse of "antipolitics," and (3) the Austrian translation strategy that construed the relations of central planning as submerged, distorted, and subordinated market relations, thus aligning the interests of East European reformers with those of Western critics of Keynesianism.

In their own accounts, East European economists felt "pushed" into becoming neoliberals as a result of their experience with reforms during socialism. ${ }^{27}$ Typically, they depict this experience as a series of failures, which clarified to them that the state socialist economy could not be reformed and needed to be abandoned altogether. We have no doubt that participation in the reform effort and the consequent disappointment played a major role in turning East European economists into shock therapists. This experience, however, must be interpreted in light of the fact that the struggle over the reforms was also a struggle over professional jurisdiction. For example, most of the reforms proposed by Hungarian, Czechoslovak, Polish, and Soviet economists during the 1960s and 1970s sought to decentralize the economy and give enterprises greater autonomy, while restricting central planning to regulation through indirect economic tools, such as subsidies and credits (Sik 1972). If fully implemented, such measures would have wrested jurisdiction over the economy from the hands of the politically trained bureaucrats, who relayed commands from the top down and supervised the behavior of state enterprises, and would

\footnotetext{
${ }^{27}$ See, e.g., Leszek Balcerowicz's "personal reflections" (Balcerowicz 1995, pp. 51-58, 341-43); or Vaclav Klaus's summary of the lessons of reforms (Klaus 1989, pp. 31-52); or János Kornai's powerful denunciations of reform thinking (Kornai 1995, pp. 1-34; Kornai 1990, pp. 58-77). For a more ambiguous account, which nonetheless concedes that the experience of reforms has turned the reformers into "transformers," see Kovács (1992).
} 
have transferred this control to economists. These reforms included legislation requiring the employment of thousands of economists, who would know how to measure the economic performance of enterprises and to calculate the interest rates and subsidies needed to regulate them "indirectly." No wonder, therefore, that bureaucrats aligned themselves with party hard-liners and vigorously resisted the reforms. Decentralizing reforms would have marginalized their expertise and subordinated them to the economists (Bockman 2000). As a result of these jurisdictional confrontations, reforms faltered according to a predictable sequence: first, the reformers drafted reform blueprints and implemented them; then, the bureaucracy sabotaged those plans, which led to inefficiencies and losses; then came the inevitable political backlash against the reforms; finally, the backlash turned into bargaining, tinkering, and modifying elements of the reform to suit the political balance of forces.

East European economists developed their economic ideas and, for some, their radical reform stance within the crucible of the struggle over professional jurisdiction and the cycle of reform. As their bid for professional jurisdiction was blocked, there were two characteristic responses of economists, each corresponding to one of the translation strategies inherited from the debate about socialist economic calculation, and each seeking to align their interests with different allies. A large group of economists turned to the neoclassical translation strategy of "formal equivalence" and focused on developing ever-more sophisticated mathematical models. These economists effectively chose to circumscribe their jurisdiction so as to avoid direct confrontations with the bureaucracy. They claimed jurisdiction over the realm of simulation and speaking from it tried to engage economic decision-makers in a dialogue and to influence them. The common basis for this dialogue was provided by the idea of the "scientific-technological revolution," which the authorities too agreed created new challenges and opportunities for Communism. They presented computerization, in particular, as promising to reconcile in the future the competing claims of bureaucrats and economists (Lange 1967; Richta et al. 1969).

The Austrian translation strategy, on the other hand, corresponded to a frontal counterattack on economic decision makers and an attempt to bring them, too, under the jurisdiction of economists. ${ }^{28}$ Thus, it was typically the choice of economists like the Czech Vaclav Klaus, who participated in CESES meetings in the late 1960s, at a time when he was still

\footnotetext{
${ }^{28}$ Indeed, economists in this group cite a fundamental debt to Hayek and Mises, and were involved during the 1980s in heretical "apartment seminars" and secretive reading projects of the Austrian thinkers (Balcerowicz 1995, pp. 35-50, 340-41; Csizmadia 1995; Klaus 1991; Komárek 1994-95).
} 
a strong supporter of reforming socialist economies. However, he fell victim to the backlash phase of the reform cycle (which in Czechoslovakia in 1969 was quite intense), was demoted, and his career was blocked. Consequently during the 1970s and 1980s his views radicalized (Eyal 2000). In contrast to their mathematical colleagues, who limited their analyses to simulations of the economic sphere, these more radical reformers have undertaken to apply economic analysis especially to political and bureaucratic institutions, since they perceived these to be the main impediments to reform (Balcerowicz 1995, pp. 1-16, 341-44; Klaus and Triska 1989; Kornai 1992). The disappointed and downwardly mobile reformers began to include political institutions within the definition of the economic, under their jurisdiction, in order to show that the obstacles or inertia that their reforms have encountered were not an external factor, but a structural component of the economic system, itself in need of reform. Hence they could use the Austrian translation strategy - encapsulated in concepts like "repressed inflation," "hidden unemployment," or "disequilibrium"- to rename and reclassify features of bureaucratic planning as systematic distortions of underlying market processes and thus align their interests with those of Western critics of bureaucratic inefficiency, for example "public choice" economists:

Reform economics was capable of providing an authentic in vivo analysis of economic disequilibrium (shortage), centralization (monopolies) and hierarchical bargaining, business cycles, state redistribution, nonmonetary transactions, shadow economy, and so on, namely, of those phenomena of excessive market distortion which could otherwise only be examined in normal market economies in small scale, almost in vitro. (Kovács 1992, pp. 318-19)

There was also a "pull" factor provided by the dissident discourse of "antipolitics." Antipolitics were not "apolitics." The former involved first and foremost a rejection of the teleological, constructive rationality of social engineering and the proposal of a competing model of intellectual work that was radically antiteleological. Any attempt to engineer society, dissidents argued, was bound to achieve precisely the opposite goal because it would ruin the very fabric of civil society, namely the qualities of individual freedom, responsibility, and self-determination. Instead, intellectuals should act more like educators and pastors, who cultivate these qualities for autonomous conduct (Eyal 2000, pp. 60-67; Konrad 1984; Shore 1998). The radical reformers fused these ideas with their own critique into a wholesale rejection of the reform logic. The concept of "civil society" thus served to recruit another set of allies by translating economic, political, and moral interests into a single critique. As against "civil society," the radical reformers depicted a socialist system, which was all of 
a piece, a coherent, if distorted, whole, and one could not simply tinker with this or that aspect of it in order to change it. Radical surgery was needed to dismantle socialist state institutions, but not in order to engage in another project of social engineering. Rather, reformers should act to liberate the natural forces of the economy and civil society, the initiative and ingenuity of responsible citizens (Balcerowicz 1995, pp. 1-16, 341-44; Klaus and Triska 1989; Kornai 1992).

This new vision of the social role of intellectuals and economists, however, meant that these intellectuals arrived at the moment of transition in 1989 burdened with a deep suspicion of "the people," whom they knew were not at all responsible or civil as required. This deep suspicion is explained by their alliance with the dissidents and by their common quest to act as pastors and moral leaders. Already during the 1970s and 1980s, both radical reformers and dissidents had opposed the social contract of "goulash communism," which in their eyes made the population accomplices of the regime in the economic and moral sense (Pithart 1989-90). This deep suspicion, rather than the arrogance of Western advisers, goes a long way toward explaining the peculiar features of the transformation strategy they proposed-that is, "shock therapy." The need for shock therapy, they explained, was to send a clear and unambiguous message to the population and to the managers of economic enterprises that this was not another "partial reform." They couched this point both as a lesson from the reform experience and as the implication of "rational expectations" theory, or the theory of "cognitive dissonance," thus translating and aligning their interests with some of the intellectual movements challenging Keynesianism in the West (Mankiw 1990). Mere reforms tended to fail because they were not radical enough; they were not able to overcome the tendency of economic actors to act on the basis of the self-fulfilling prophecy that things will remain the same and the tendency of the authorities to renege on their policies (the inevitable political backlash); and reform as it had heretofore been practiced did not produce a sharp enough "cognitive dissonance" to disabuse economic actors of their old ways (Balcerowicz 1995, pp. 51-58, 320-21, 342-44; Klaus 1989, pp. 45-48).

We see, therefore, how false it is to assume that "shock therapy" was imposed on the postcommunist countries by Western economists and the IMF. By the mid-1980s, virtually all the future "transformers" had already reached the conclusion that the socialist economy was bankrupt. They depicted it as nothing but a system of "destroyed capitalism," suffering from "extreme macroeconomic imbalance," on the verge of a "macroeconomic disaster." There was no time to lose, but neither could one play any longer with the sort of reforms, which were only "the imitation of capitalism under increasingly relaxed constraints." The only way to overcome the economic problems of socialism was to transform it completely 
into market capitalism. Moreover, such transformation could not, by definition, be achieved gradually, but must be implemented with the utmost speed.

It is necessary to initiate [transition] out of "nothing," from the situation of misinforming prices expressing one-sidedly only costs, but not reflecting thus far appreciation from the user's side; from the situation of soft budgetary limitations . . . ; from the situation in which . . . loss of profitability cannot be memento mori for the enterprise concerned. And yet there is no other option than to delegate decision-making on structure to the enterprise level "at once," without waiting for prerequisites to be created for it. . . . We must simply re-orientate ourselves with full consistency. . . The first step must be the shock of the realization that it is not possible to continue steering the old course. (Jezek and Turek 1989, p. 66) ${ }^{29}$

The overnight implementation of neoliberal stabilization and liberalization policies in Poland, Czechoslovakia, Hungary, and the Soviet Union during 1989-91 was thus not simply a ceremonial bow to the orthodox Western doctrine, "the transition according to Cambridge, Mass." (Murrell 1995), but was interpreted by East European economic transformers as in direct continuity with the lessons they have learned from the era of reform. If the stories and recommendations of the radical reformers accorded with Western neoliberals, at least for the time being, this was neither because they were the truth about economic reality, nor because they reflected the need to accommodate the wishes of Western lending institutions,${ }^{30}$ but because of the Austrian translation strategy that over time, in the course of transnational dialogue during the Cold War, aligned their interests. Many of the new economic decision makers, or their advisers, who undertook to draw transition blueprints and implement them, had participated earlier in East-West conferences and academic exchanges. In Russia, Prime Minister Gaidar's team of economists included, among others, Petr O. Aven, Stanislav Shatalin, and E. Yasin, all of whom worked with Western economists in Vienna's IIASA. Two of the top economic advisers to the Hungarian government, Janos Kornai and Tamas Nagy, participated in Mieli's East-West conferences, though one

\footnotetext{
${ }^{29}$ See also Balcerowicz (1995, pp. 51-58, 314-20, 341-43, 365). He notes that on the matter of "shock therapy" he had complete agreement with the Russian economists Kagalovski, Yavlinsky, and Gaidar.

30 "One should distinguish between external influences with respect to the content of the economic program and those factors that affected internal support for the program. In the Polish case, the latter was much more important than the former. In negotiations with the IMF, multilateral banks and Western governments, there was very little pressure with respect to economic strategy and its crucial details because the Polish program was basically in line with the goals of these organizations" (Balcerowicz 1995, p. 310).
} 
could by no means describe them as "students" of the Western economists. The same was true for Vaclav Klaus, the Czech finance minister and later prime minister, and for his closest collaborators, Tomas Jezek and Dusan Triska (minister of privatization and deputy finance minister, respectively), as well as for Poland's first finance minister, Leszek Balcerowicz.

Yet, the American economists and consultants who arrived in Eastern Europe and the Soviet Union after 1989 were unaware of this dialogue and were surprised to find a consensus around neoliberalism This was because, as we saw, the forgetting of the dialogue was produced by the network itself and contributed to its functioning. It permitted American economists, once again, to interpret this consensus as "data," further proof of the correctness and universality of their models. ${ }^{31}$ The transnational dialogue was forgotten and observers simply perceived the diffusion of neoliberalism from West to East. In conclusion, we would like to recount an anecdote, whose ironic conclusion casts into sharp relief all the different aspects of the story related here about the transnational network, the existence of a domestic constituency for neoliberalism, the translation and alignment of interests, the built-in forgetting and misrecognition of neoliberalism as "Western."

In 1989, Gorbachev sent his senior advisor to IIASA in Vienna to request the institute's assistance in organizing a team of American economists, preferably from Harvard, Yale, or Princeton, to serve as consultants on the transition to a market society. The Russians must have approached IIASA because the institute was familiar to them as one of the prime links in the chain of transnational ties organized around mathematical economics during the Cold War period. Gorbachev's instructions, however, specified that the Russians were not interested in economists who specialized in the study of socialist economies, but rather in those who were experts on the workings of market economies. By a curious stroke of fate, the American economists who eventually teamed up with Gorbachev's men were all from Yale. The Russians were in a hurry and Princeton and Harvard were still in session. The Yale economists were not strident free-market advocates. They included some former advisors to Democratic administrations who had supported state intervention in the economy. These economists were not knowledgeable about socialist economies or the Russian economy, and they treated the Russians economists' papers and reports as "data," "on the ground" information.

\footnotetext{
${ }^{31}$ Wedel (2001) interviewed East European and Russian economists working in ministries, who reported spending most of their time providing information to foreign experts, because these experts did not know much about the domestic situation. Foreign experts then wrote proposals, based on the "data," which ministry economists found useless because they restated what they already knew.
} 
American Journal of Sociology

The Yale economists worked in tandem with a group of Gorbachev's advisers, composed of Russian economists like Anatoly Chubais, E. Yasin, G. A. Yavlinsky, and Peter O. Aven. Virtually all of these individuals were previously involved in the struggles over reforms and economic jurisdiction, and by 1989 had evolved into the type of radical reformers described above. The Yale economists report that they were "surprised" not to have any big disagreements with the Russians at their meetings. One American economist had arrived prepared "to do battle," but found the meetings to be "a love fest." ${ }^{32}$

There was, nonetheless, some disagreement. As in many other East European countries in transition, the main question was whether to transform the economy swiftly through "shock therapy," or whether to opt for a more gradual approach. In one of those beautiful moments of historical irony, the American economists argued for gradualism, while most of the Russian reformers called for shock therapy. ${ }^{33}$ The Russians' preference for "shock therapy" was justified in terms of the Austrian translation strategy: the socialist system was composed of "distorted" markets, prices were not conveying reliable information to economic actors, and state ownership was a form of monopoly that led to vested interests and rent seeking. Moreover, this system was "all of a piece," with its "own internal consistency" (Schneider 1990, p. 41). The system was in deep crisis, not least because previous reforms were inconsistent, contradictory, and never complete. This meant, therefore, that a much more thorough reform was required, in particular the complete removal of the state from economic life. And this must be done from above, preferably without consulting the public, because it was going to be "painful" and ordinary citizens could not be trusted to support market reforms. They were shaped by the socialist system into "administrative men" rather than "economic men" and would support "populist" policies. For all these reasons, there was no other way but to opt for "emergency measures" and "shock therapy" (Yasin 1990, pp. 20-21). The Russians explained to their stunned American colleagues that they too should be interested in these lessons, which were derived from the reform experience, because "such problems of the transition as debureaucratization and decentralization of management are of universal significance. Therefore, Eastern Europe may, to some degree, turn out to be 'proving grounds' for identifying feasible solutions" (Aven

\footnotetext{
${ }^{32}$ Confidential interview conducted April 24, 2001, with an American economist who participated in the IIASA meetings.

${ }^{33}$ Nordhaus (1990), e.g., argued against shock therapy: "In my opinion, such an approach is too risky for as large, closed, and hierarchical an economy as the Soviet Union. As an economist, I simply could not guarantee that such an abrupt transition would not lead to a major breakdown of the economy" (p. 148).
} 
et al. 1990, p. 7). In short, shock therapy was not only recommended in order to save Eastern economies, but also to serve as a laboratory experiment supporting Western economic theories.

\section{CONCLUSIONS}

In this article we sought to elucidate the causes for the rapid and enthusiastic embrace of neoliberal economic policies in Eastern Europe after the fall of Communism. Unlike the many accounts that attribute neoliberalism's success to international pressure, blind imitation, or the need for legitimacy, we argued that it was due to an existing transnational network and dialogue. Following Latour, we suggested that the drafting of postcommunist transition blueprints, even with the participation of American economists, should not be analyzed as the diffusion of an innovation from West to East, but as translation meant to align the interests of Western and East European economists and reinforce their transnational ties. Within this transnational network it was impossible to assign the role of active authors to American economists and passive recipients to East European economists. In this case at least, neoliberalism was not a preexisting theory or ideology that was disseminated from West to East, but was itself synonymous with the network that connected American and East European economists and with the translation strategy that coordinated their interests.

We have suggested that new institutionalist sociologists would do well to pay attention not only to processes of diffusion, but also to how institutional forms are reproduced, and, we suggest, following Latour, that this case allows us to think of institutional forms as actor-networks. Our understanding of the operation of the actor-network allowed us to perceive dialogue and alignment of interests, where others saw only imitation and imposition. We began with the socialist calculation debate and showed that it constituted a central discursive event in the history of neoliberalism by making socialism into a laboratory for economic knowledge. We also showed that Austrian and mathematical economists developed two different translation strategies in order to connect results obtained in the laboratory to debates about market economics. We then documented an extensive Cold War dialogue between American and East European economists, on the basis of these translation strategies, which permitted them to align their interests and use their network allies to fight their own professional and political battles at home. Finally, we documented the importance of these ties and translation strategies even in what was perceived as the triumph of Western neoliberalism, that is, the design of transition blueprints in Eastern Europe after the fall of Communism. 
While we emphasized the hybrid origins of neoliberalism, we also analyzed the power relations intrinsic to transnational actor-networks in order to explain why neoliberal policies appeared to most observers to have originated with and been imposed by American economists. We showed that the network itself as part of its regular functioning produced this appearance. American economists occupied an obligatory point of passage within the network, which allowed them to mobilize the discourse of their interlocutors and present it as "data." Thus, the interests of network participants were aligned by a translation strategy, which cast postcommunist reform as a crucial laboratory experiment validating Western economic theories.

We hope that this modest demonstration could be extended in the future into a more general investigation of the origins of neoliberalism and the causes for its global success. Up until now, the few attempts to provide such an account focused on the larger macroeconomic or political context, such as the economic crises of the 1970s, stagflation and oil price shocks, the rise of global financial markets, and the victories of conservative political forces (Kelly 1997; Harvey 1989). These events were seen as either providing the definitive proof that Keynesianism was incorrect or as simply implementing the interests of large multinational capital. We hope that our article provokes a more nuanced investigation, one that follows the networks constructed by economists, policy makers, and business firms, rather than too quickly extrapolates to larger causes. Why would such nuance be important? Are we just quibbling about theoretical niceties while the big picture is one of globalization-cum-Americanization? We do not think so. If one is convinced that the global spread of neoliberalism is simply the result of a monologue propounded by U.S. economists and policymakers to the rest of the globe, one is making one's task too easy. One is tempted to believe that there is an easy answer and an easy target for resistance: attack the IMF, the World Bank, and the U.S. Federal Reserve; cultivate the local against the global; denounce abstract, universalizing discourse formulated from the point of view of the mighty. According to this view, if we could only get rid of these centers and let those on the periphery determine their own fate, then we could avert the dangers of neoliberalism . But if the analysis we presented here is correct, the task of resisting neoliberalism is much more difficult. By no means would the periphery provide a stable point outside the networks that constitute neoliberalism, from which to analyze and resist it. 
Economic Knowledge

\section{APPENDIX}

Table A1 lists the Hungarian economists who participated in Ford Foundation exchanges from 1964 to 1969 . This is an incomplete list based on information from the Ford Foundation Archive (R2346, R2347).

TABLE A1

ExCHANGE PARTICIPANTS

\begin{tabular}{|c|c|}
\hline Year/Name & Professional Affiliation \\
\hline \multicolumn{2}{|l|}{ 1964-65: } \\
\hline József Bognár . & $\begin{array}{l}\text { Director, Afro-Asian Research Group (1965) and cultural } \\
\text { exchange program }\end{array}$ \\
\hline András Bródy ....... & Mathematical economist, Economic Science Institute \\
\hline György Péter ........ & Director, Central Statistical Office \\
\hline József Sebestyen .... & Mathematical agricultural economist \\
\hline Júlia Zala .......... & Official in the Central Statistical Office \\
\hline \multicolumn{2}{|l|}{ 1965-66: } \\
\hline Lajos Ács ..... & $\begin{array}{l}\text { Head, Department for Economic Research at the Hungarian } \\
\text { National Bank. }\end{array}$ \\
\hline Gyula Bora ........ & Economic geographer, Economics University \\
\hline János Hoos ......... & $\begin{array}{l}\text { Mathematical economist, National Planning Office; instructor, } \\
\text { Economics University }\end{array}$ \\
\hline Béla Krekó .... & $\begin{array}{l}\text { Mathematical economist; instructor, Economics University; di- } \\
\text { rector, Economic University Computer Center }\end{array}$ \\
\hline József Nyilas ........ & Instructor in international economics, Economics University \\
\hline György Ranki ....... & Economic historian \\
\hline Ann Simon .... & $\begin{array}{l}\text { Planning and mathematical economist, Central Statistical } \\
\text { Office }\end{array}$ \\
\hline \multicolumn{2}{|l|}{ 1966-67: } \\
\hline Iván Berend ........ & Economic historian and later head, Economics University \\
\hline Béla Mártos ......... & Mathematical economist, Economic Science Institute \\
\hline Tibor Palánkai ...... & Instructor of international economics, Economics University \\
\hline \multicolumn{2}{|l|}{ 1967-68: } \\
\hline Béla Kádá ........... & $\begin{array}{l}\text { Economist, Afro-Asian Research Group (later, Institute on the } \\
\text { World Economy) }\end{array}$ \\
\hline György Kondor ..... & Mathematical economist, Economic Science Institute \\
\hline András Raba ........ & $\begin{array}{l}\text { International economist at the Cycles and Market Research } \\
\text { Institute }\end{array}$ \\
\hline György Varga & $\begin{array}{l}\text { Editor, Figyelö (economic weekly); member, National Commit- } \\
\text { tee for Management }\end{array}$ \\
\hline \multicolumn{2}{|l|}{ 1968-69: } \\
\hline Miklós Márton ....... & Economic journalist, Népszabadság; editor, Gazdaság \\
\hline Tibor Nagy ......... & Financial law professor, ELTE \\
\hline András Nyilas ...... & Department head, Economic Science Institute. \\
\hline Ferenc Rabar ....... & $\begin{array}{l}\text { Director, Laboratory for Information Processing (management } \\
\text { science group) }\end{array}$ \\
\hline
\end{tabular}

Note.-All institutions mentioned in table A1 are located in Budapest. 


\section{American Journal of Sociology}

\section{REFERENCES}

Abbott, Andrew. 1988. The System of Professions: An Essay on the Division of Expert Labor. Chicago: Chicago University Press.

$\rightarrow$ Adler, Emanuel, and Peter M. Haas. 1992. "Conclusion: Epistemic Communities, World Order, and the Creation of a Reflective Research Program." International Organization 46:367-90.

Aidenoff, Abraham. 1970. "Input-Output Data in the United Nations System of National Accounts." Pp. 349-68 in Contributions to Input-Output Analysis. Proceedings of the Fourth International Conference on Input-Output Techniques, Geneva, January 8-12, 1968. Vol. 2, edited by A. P. Carter and A. Bródy. Amsterdam: North-Holland Publishing Company.

Appadurai, Arjun. 1996. Modernity at Large: Cultural Dimensions of Globalization. Minneapolis: University of Minnesota Press.

Arrow, Kenneth J., and Leonid Hurwicz. 1960. "Decentralization and Computation in Resource-Allocation." Pp. 34-104 in Essays in Economics and Econometrics in Honor of Harold Hottelling, edited by R. W. Fouts. Chapel Hill: University of North Carolina Press.

$\rightarrow$ Ashley, Richard K. 1983. "The Eye of Power: The Politics of World Modeling." International Organization 37:495-535.

Aslund, Anders. 1992. Post-Communist Economic Revolutions: How Big a Bang? Washington, D.C.: Center for Strategic and International Studies.

Aven, P. O., S. S. Shatalin, and F. Schmidt-Bleek. 1990. "Introduction." Pp. 1-7 in Economic Reform and Integration, Proceedings of 1-3 March 1990 Meeting, edited by P. O. Aven, S. S. Shatalin, and F. Schmidt-Bleek. Laxenburg: International Insitute for Applied Systems Analysis (IIASA).

Babb, Sarah L. 2001. Managing Mexico: Economists from Nationalism to NeoLiberalism. Princeton, N.J.: Princeton University Press.

Balas, Egon. 2000. Will to Freedom: A Perilous Journey through Fascism and Communism. Syracuse, N.Y.: Syracuse University Press.

Balcerowicz, Leszek. 1995. Socialism, Capitalism, Transformation. Budapest: CEU Press.

Barghoorn, Frederick C. 1960. The Soviet Cultural Offensive: The Role of Cultural Diplomacy in Soviet Foreign Policy. Princeton, N.J.: Princeton University Press.

Bernstein, Michael A. 2001. A Perilous Progress: Economists and Public Purpose in 20th Century America. Princeton, N.J.: Princeton University Press.

$\rightarrow$ Blanchard, Oliver. 1999. "An Interview with János Kornai.” Macroeconomic Dynamics 3:427-50.

Bockman, Johanna K. 2000. Economists and Social Change: Science, Professional Power, and Politics in Hungary, 1945-1995. Ph.D. dissertation. University of California, San Diego, Department of Sociology.

Boetkke, Peter J. 2000. Socialism vs. the Market: The Socialist Calculation Debate. London: Routledge.

Byrnes, Robert. 1976. Soviet-American Academic Exchanges, 1958-1975. Bloomington: Indiana University Press.

Campbell, Robert W. 1963. "Mathematics in Soviet Planning, and the Theory of Value." Pp. 102-18 in Capitalism, Market Socialist, and Central Planning, edited by Wayne A. Leeman. Boston: Houghton Mifflin Company.

Centeno, Miguel. 2001. "Isomorphic Neo-liberalism and the Creation of Inevitability." Paper presented at the miniconference, Global Change, Institution Building, and the Role of Economists in Public Policy Making. Amsterdam, June 30.

Chenery, Hollis B. 1970. "Introduction." Pp. 1-6 in Contributions to Input-Output Analysis. Proceedings of the Fourth International Conference on Input-Output 
Techniques, Geneva, January 8-12, 1968. Vol. 2, edited by A. P. Carter and A. Bródy. Amsterdam: North-Holland Publishing Company.

Cockett, Richard. 1995. Thinking the Unthinkable: Think-Tanks and the Economic Counter-Revolution, 1931-1983. London: Harper Collins Publishers.

Csizmadia, Ervin. 1995. A Magyar Demokratikus Ellenzék (1968-1988), vol. 1. Budapest: T-Twins Kiadó.

Cummings, Bruce. 1998. "Boundary Displacement: Area Studies and International Studies During and After the Cold War." Pp. 159-88 in Universities and Empires: Money and Politics in the Social Sciences during the Cold War, edited by Christopher Simpson. New York: New Press.

Evangelista, Matthew. 1999. Unarmed Forces: The Transnational Movement to End the Cold War. Ithaca, N.Y.: Cornell University Press.

$\rightarrow$ Eyal, Gil. 2000. "Anti-Politics and the Spirit of Capitalism: Dissidents, Monetarists and the Czech Transition to Capitalism." Theory and Society 29:49-92.

Fisher, Harold H., ed. 1959. American Research on Russia. Bloomington: Indiana University Press.

Fleron, Frederic J., Jr., and Erik P. Hoffman. 1993. Post-Communist Studies and Political Science. Boulder, Colo.: Westview Press.

Foucault, Michel. 1972. The Archeology of Knowledge. London: Tavistock.

Fourcade-Gourinchas, Marion. 2000. "The National Trajectories of Economic Knowledge: Discipline and Profession in the United States, Great Britain, and France." Ph.D. dissertation. Harvard University, Department of Sociology.

Friedman, Milton. 1981. Market Mechanisms and Central Economic Planning. Washington, D.C.: Thomas Jefferson Center Foundation.

Friedman, Milton, and Rose D. Friedman. 1998. Two Lucky People: Memoirs. Chicago: University of Chicago Press.

Galbraith, John Kenneth. 1958. Journey to Poland and Yugoslavia. Cambridge, Mass.: Harvard University Press.

Gleason, Abbott. 1995. Totalitarianism: The Inner History of the Cold War. New York: Oxford University Press.

Grosfeld, Irena. 1992. "Reform Economics and Western Economic Theory: Unexploited Opportunities.” Pp. 62-79 in Reform and Transformation in Eastern Europe, edited by Janos Matyas Kovacs and Marton Tardos. London: Routledge.

Guillen, Mauro F. 2001. "Is Globalization Civilizing, Destructive or Feeble? A Critique of Five Key Debates in the Social Science Literature." Annual Review of Sociology 27.

Haas, Ernst B. 1990. When Knowledge Is Power: Three Models of Change in International Organizations. Berkeley and Los Angeles: University of California Press.

$\rightarrow$ Haas, Peter M. 1992. "Introduction: Epistemic Communities and International Policy Coordination." International Organization 46:1-35.

$\rightarrow$ Hall, Peter A. 1993. "Policy Paradigms, Social Learning, and the State: The Case of Economic Policymaking in Britain." Comparative Politics 25:275-96.

Hartwell, R. M. 1995. A History of the Mont Pelerin Society. Indianapolis: Liberty Fund.

Harvey, David. 1989. The Condition of Post-Modernity. Oxford: Basil Blackwell.

Hayek, Friedrich A. von. 1935. Collectivist Economic Planning. London: George Routledge \& Sons.

. 1939. Freedom and the Economic System. Public Policy Pamphlet no. 29. Chicago: University of Chicago Press.

. 1948. Individualism and Economic Order. Chicago: University of Chicago Press.

Jepperson, Ronald L. 1991. "Institutions, Institutional Effects, and Institutionalism." 


\section{American Journal of Sociology}

Pp. 143-63 in The New Institutionalism in Organizational Analysis, edited by Walter W. Powell and Paul J. Dimaggio. Chicago: University of Chicago Press.

Jessop, Bob. 1999. "Narrating the Future of the National Economy and the National State: Remarks on Remapping Regulation and Reinventing Governance." Pp. 378-405 in State/Culture: State Formation after the Cultural Turn, edited by George Steinmetz. Ithaca, N.Y.: Cornell University Press.

Jezek, Tomas, and Otakar Turek. 1989. "Structural Changes and the Economic Mechanism." Czechoslovak Economic Digest 7 (November): 53-77.

Keck, Margaret E., and Kathryn Sikkink, eds. 1998. Activists beyond Borders: Advocacy Networks in International Politics. Ithaca, N.Y.: Cornell University Press.

Kelley, John L. 1997. Bringing the Market Back In: The Political Revitalization of Market Liberalism. New York: New York University Press.

King, Lawrence P. 2001. The Basic Features of Post-Communist Capitalism in Eastern Europe. London: Pragaer.

Klaus, Vaclav. 1989. "The Imperatives of Long-term Prognoses and the Dominant Characteristics of the Economy at Present." Czechoslovak Economic Digest 7 (November): $31-52$.

. 1991. "Creating a Capitalist Czechoslovakia: An Interview with Václav Klaus." Pp. 149-56 in After the Velvet Revolution: Václav Havel and the New Leaders of Czechoslovakia Speak Out, edited by Tim D. Whipple. New York: Freedom House.

Klaus, Vaclav, and Dusan Triska. 1989. "The Economic Center: The Restructuring and Equilibrium." Czechoslovak Economic Digest 1:34-56.

Komárek, Martin. 1994-95. GEN - 100 Cechu Dneška. Prague: Fischer.

Konrad, George. 1984. Antipolitics: An Essay. New York: Harcourt Brace Jovanovich. Kornai, János. 1990. The Road to a Free Economy. New York: W. W. Norton. 1992. The Socialist System. Princeton, N.J.: Princeton University Press.

1995. "Market Socialism Revisited." Pp. 1-34 in Highways and Byways: Studies on Reform and Post-Communist Transition. Cambridge, Mass.: MIT Press.

Kovács, János Mátyás. 1991. "From Reformation to Transformation: Limits to Liberalism in Hungarian Economic Thought." East European Politics and Societies 5:41-72.

- 1992. "Compassionate Doubts about Reform Economics." Pp. 299-333 in Reform and Transformation in Eastern Europe, edited by János Mátyás Kovács and Marton Tardos. London: Routledge.

Lange, Oskar. 1938. "On the Economic Theory of Socialism." Pp. 55-143 in On the Economic Theory of Socialism, edited by Benjamin E. Lippincott. Minneapolis: University of Minnesota Press.

. 1967. "The Computer and the Market." Pp. 158-61 in Socialism, Capitalism and Economic Growth: Essays Presented to Maurice Dobb, edited by C. H. Feinstein. Cambridge: Cambridge University Press.

Latour, Bruno. 1987. Science in Action. Cambridge, Mass.: Harvard University Press. Press.

Lavoie, Don. 1985a. National Economic Planning: What Is Left? Cambridge, Mass.: Ballinger.

- 1985b. Rivalry and Central Planning: The Socialist Calculation Debate Reconsidered. Cambridge: Cambridge University Press.

Leontief, Wassily. 1963. "The Decline and Rise of Soviet Economic Science." Pp. 91-101 in Capitalism, Market Socialist, and Central Planning, edited by Wayne A. Leeman. Boston: Houghton Mifflin.

Leontief, Wassily, et al. 1977. The Future of the World Economy: A United Nations Study. New York: Oxford University Press.

Lindbeck, Assar. 1971. The Political Economy of the New Left: An Outsider's View. New York: Harper \& Row. 
$\rightarrow$ Lipton, David, and Jeffrey Sachs. 1990. "Creating a Market Economy in Eastern Europe: The Case of Poland." Brookings Papers on Economic Activity 1:75-133.

$\rightarrow$ Mankiw, Gregory N. 1990. "A Quick Refresher Course in Macroeconomics." Journal of Economic Literature 28 (December): 1645-60.

$\rightarrow$ Markoff, Jonathan, and Veronica Montecinos. 1993. "The Ubiquitous Rise of Economists." Journal of Public Policy 13:37-68.

$\rightarrow$ Meyer, John W., John Boli, G. M. Thomas, and F. O. Ramirez. 1997. "World Society and the Nation-State." American Journal of Sociology 103:144-87.

Meyer, John W., and Brian Rowan. 1991. "Institutionalized Organizations: Formal Structure as Myth and Ceremony." Pp. 41-62 in The New Institutionalism in Organizational Analysis, edited by Walter W. Powell and Paul J. DiMaggio. Chicago: University of Chicago Press.

Mises, Ludwig von. (1920) 1935. "Economic Calculation in the Socialist Commonwealth.” Pp. 87-130 in Collectivist Economic Planning, edited by F. A. von Hayek. London: George Routledge \& Sons.

Morgan, Mary S. 1990. The History of Economic Ideas. Cambridge: Cambridge University Press.

$\rightarrow$ Morgan, Mary S., and Malcolm Rutherford. 1998. "American Economics: The Character of the Transformation." History of Political Economy 30 (suppl.): 1-29.

$\rightarrow$ Murrell, Peter. 1995. "The Transition According to Cambridge, Mass." Journal of Economic Literature 33:164-78.

Nederveen Pieterse, Jan. 1992. Globalization as Hybridization. The Hague: Publications Office, Institute of Social Studies.

Nordhaus, W. D. 1990. "Comments on the Paper by K. Kagalovsky and A. Khandruyev." Pp. 145-55 in Economic Reform and Integration, Proceedings of 1-3 March 1990 Meeting, edited by P. O. Aven, S. S. Shatalin, and F. Schmidt-Bleek. Laxenburg: IIASA.

Pithart, Petr. 1989-90. "Social and Economic Developments in Czechoslovakia in the 1980s, pt. 1." East European Reporter 4 (1): 42-45.

Portes, Richard. 1983. "Central Planning and Monetarism: Fellow Travelers?" Pp. 149-65 in Marxism, Central Planning, and the Soviet Economy: Economic Essays in Honor of Alexander Erlich, edited by Padma Desai. Cambridge, Mass.: MIT Press.

Poundstone, William. 1993. Prisoners' Dilemma: John von Neumann, Game Theory, and the Puzzle of the Bomb. New York: Anchor Books.

Powell, Walter W., and Paul J. DiMaggio, eds. 1991. The New Institutionalism in Organizational Analysis. Chicago: University of Chicago Press.

Prybyla, Jan S. 1969. Preface to Comparative Economic Systems. New York: Meredith Corporation.

Raynor, Gregory Kenneth. 2000. Engineering Social Reform: The Rise of the Ford Foundation and Cold War Liberalism, 1908-1959. Ph.D. dissertation. New York University, Department of History.

Reich, Robert. 1991. The Work of Nations. New York: Vintage Books.

Richmond, Yale. 1987. U.S.-Soviet Cultural Exchanges, 1958-1986: Who Wins? Boulder, Colo.: Westview Press.

Richta, Radovan, et al. 1969. Civilization at the Crossroads. Prague: International Arts and Sciences Press.

Robin, Ron. 2001. The Making of the Cold War Enemy: Culture and Politics in the Military-Intellectual Complex. Princeton, N.J.: Princeton University Press.

Schneider, C. M. 1990. "Summary of Discussions." Pp. 41-46 in Economic Reform and Integration, Proceedings of 1-3 March 1990 Meeting, edited by P. O. Aven, S. S. Shatalin, and F. Schmidt-Bleek. Laxenburg: IIASA.

Shearmur, Jeremy. 1996. Hayek and After: Hayekian Liberalism as a Research Program. London: Routledge. 
American Journal of Sociology

$\rightarrow$ Shore, Marci. 1998. "Engineering in the Age of Innocence: A Genealogy of Discourse inside the Czechoslovak Writer's Union, 1949-67." Eastern European Politics and Societies 12 (3): 397-441.

Sik, Ota. 1972. Czechoslovakia: The Bureaucratic Economy. White Plains, N.Y.: IAS Press.

Stigler, George J. 1988. Memoirs of an Unregulated Economist. New York: Basic Books.

Such, György, and István János Tóth. 1989. "A magyar közgazdaságtudomány a Közgazdasági Szemle tudománymetriai vizsgálatának tükrében [Hungarian economics as reflected in a scientometric analysis of the Economic Review].” Közgazdasági Szemle 36:1163-1241.

$\rightarrow$ Sutton, Francis X. 1987. "The Ford Foundation: The Early Years." Daedalus 116: 41-91.

Tilly, Charles. 1999. "Epilogue: Now Where?" Pp. 407-19 in State/Culture: State Formation after the Cultural Turn, edited by George Steinmetz. Ithaca, N.Y.: Cornell University Press.

Turgeon, Lynn. 1971. "Economic Concepts: The Delicate Balance between Realism and Romance." Pp. 19-36 in Planning and Market Relations: Proceedings of a Conference Held by the International Economic Association at Liblice, Czechoslovakia, edited by Michael Kaser and Richard Portes. London: Macmillan Press.

Wedel, Janine. 2001. Collision and Collusion. New York: St. Martin's Press.

Weintraub, E. Roy. 1985. General Equilibrium Analysis: Studies in Appraisal. Cambridge: Cambridge University Press.

$\rightarrow$ Wimmer, Andreas. 2001. "Globalizations Avant la Lettre: A Comparative View of Isomorphization and Heteromorphization in an Inter-Connecting World." Comparative Studies in Society and History 43:435-66.

Yasin, E. 1990. "Modern Market Institutions and Problems of the Economic Reform in the USSR." Pp. 11-21 in Economic Reform and Integration, Proceedings of 1-3 March 1990 Meeting, edited by P. O. Aven, S. S. Shatalin, and F. Schmidt-Bleek. Laxenburg, Austria: IIASA.

Yonay, Yuval. 1998. The Struggle over the Soul of Economics: Institutionalist and Neoclassical Economists in American between the Wars. Princeton, N.J.: Princeton University Press.

Zieleniec, Jozef. 1990. "Micro-Economic Categories in Different Economic Systems: The Firm." Pp. 3-9 in Optimal Decisions in Markets and Planned Economies, edited by R. E. Quandt and D. Tríska. Boulder, Colo.: Westview Press.

Zucker, L. 1991. "The Role of Institutionalization in Cultural Persistence." Pp. 83-107 in The New Institutionalism in Organizational Analysis, edited by Walter W. Powell and Paul J. DiMaggio, Chicago: University of Chicago Press. 